\title{
MicroRNAs and 'Sponging' Competitive Endogenous RNAs Dysregulated in Colorectal Cancer: Potential as Noninvasive Biomarkers and Therapeutic Targets
}

\author{
Brian G. Jorgensen and Seungil Ro*(D)
}

check for updates

Citation: Jorgensen, B.G.; Ro, S. MicroRNAs and 'Sponging' Competitive Endogenous RNAs Dysregulated in Colorectal Cancer: Potential as Noninvasive Biomarkers and Therapeutic Targets. Int. J. Mol. Sci. 2022, 23, 2166. https:// doi.org/10.3390/ijms23042166 Academic Editors: Alessandro Ottaiano and Donatella Delle Cave

Received: 20 January 2022 Accepted: 2 February 2022 Published: 16 February 2022

Publisher's Note: MDPI stays neutral with regard to jurisdictional claims in published maps and institutional affiliations.

Copyright: (C) 2022 by the authors. Licensee MDPI, Basel, Switzerland. This article is an open access article distributed under the terms and conditions of the Creative Commons Attribution (CC BY) license (https:// creativecommons.org/licenses/by/ $4.0 /)$.
Department of Physiology \& Cell Biology, University of Nevada, Reno School of Medicine, Reno, NV 89557, USA; brianjorgensen@med.unr.edu

* Correspondence: sro@med.unr.edu; Tel.: +1-775-784-1462

\begin{abstract}
The gastrointestinal (GI) tract in mammals is comprised of dozens of cell types with varied functions, structures, and histological locations that respond in a myriad of ways to epigenetic and genetic factors, environmental cues, diet, and microbiota. The homeostatic functioning of these cells contained within this complex organ system has been shown to be highly regulated by the effect of microRNAs (miRNA). Multiple efforts have uncovered that these miRNAs are often tightly influential in either the suppression or overexpression of inflammatory, apoptotic, and differentiation-related genes and proteins in a variety of cell types in colorectal cancer (CRC). The early detection of CRC and other GI cancers can be difficult, attributable to the invasive nature of prophylactic colonoscopies. Additionally, the levels of miRNAs associated with CRC in biofluids can be contradictory and, therefore, must be considered in the context of other inhibiting competitive endogenous RNAs (ceRNA) such as lncRNAs and circRNAs. There is now a high demand for disease treatments and noninvasive screenings such as testing for bloodborne or fecal miRNAs and their inhibitors/targets. The breadth of this review encompasses current literature on well-established CRC-related miRNAs and the possibilities for their use as biomarkers in the diagnoses of this potentially fatal GI cancer.
\end{abstract}

Keywords: colorectal cancer; miRNA; ceRNA; lncRNA; circRNA; sponging; noninvasive biomarkers

\section{Introduction}

As a generalized class of biomolecules, RNA species occupy a unique niche that can alternate between being transient and/or enduring, while being consequential or seemingly neutral to cellular homeostasis, growth, and survival across a myriad of taxonomic levels of life. While RNA has been known as a unique biomolecule since the 19th century, it came to the forefront of biological study in the mid-20th century upon the discovery that various RNA molecules were, collectively, the transcript, delivery, and production scaffolding for translating the genetic information contained within DNA into functional proteins via ribosomes. However, in the decades since those foundational studies, it has been found that a vast majority of the biological activity of RNA species is not as transcript templates (messenger RNA (mRNA)) for protein synthesis, but rather regulators of gene expression. These non-mRNA RNA transcripts do not primarily function as templates for protein translation and, thus, are called noncoding RNAs (ncRNA). One important class of endogenous regulatory ncRNAs are microRNAs (miRNA), which are 21-25 nucleotides in length when mature following enzymatic processing. Following their initial discoveries as endogenously produced transcripts, it was found that the dysregulation of many specific ncRNAs are tied to malignancies in humans [1-4]. Subsequent studies into each individual/category of ncRNA built upon these discoveries of dysregulated ncRNA expression to reveal the modes of action on cellular pathways known to be causative in carcinogenesis. Certain miRNAs were found to be key regulators of well-established carcinogenic pathways such as miR-143 and miR-145, acting as tumor suppressors on the p53/c-Myc pathway [5,6], 
the circular RNA (circRNA) Cdr1as sequestering miR-7, reducing its ability to regulate the proto-oncogenic PI3K/AKT pathway [7,8], and the long noncoding RNA (lncRNA) GAS5-controlling mTOR-mediated proliferation via the competitive binding of glucocorticoid receptors and miR-21 $[9,10]$. While these miRNAs can affect many distinct cellular pathways, there is oftentimes an overlap and/or interplay between unique ncRNAs classes that results in the pathological alterations of many signaling pathways at the cellular level. This can manifest, for example, when lncRNAs or circRNAs competitively sequester miRNAs from their targeted mRNAs (collectively known as competitive endogenous RNAs, ceRNA) through complementary base pairing, known as "sponging", as seen between the long noncoding RNA (lncRNA) HOTAIRM1 or the circular RNA (circRNA) circITCH and miR-17 [11,12]. Colorectal cancer (CRC) most commonly manifests as neoplasias consisting mainly of mutated intestinal epithelial cells that are unable to maintain a proper differentiation status and/or connections to neighboring cells, leading to unchecked cellular division and the dysregulation of oncogenic and/or tumor-suppressive genes [13,14]. Most CRC cases do not yet have a prescribed causative provenance and are, thus, considered sporadic (70\%) [15]. For decades, invasive colonoscopies have been the most common form of early detection for CRC and they luckily reduce the death rate by about $50 \%[16,17]$. Unfortunately, this reduction in mortality appears to be largely associated with carcinomas found on the left side of the colon as they are easier to observe and remove [18], leaving around $10 \%$ of all CRCs undetectable via colonoscopy [19]. This inability to robustly detect CRC regardless of the location provides the impetus to find biomarkers, such as miRNAs, in excreted bodily fluids (stool/serum/plasma) that could potentially diagnose CRC in various colonic regions. These strategies of measuring levels of known oncogenes in bodily fluids (mainly serum, plasma, or stool) have already begun to be investigated and employed for miRNA [20-22], lncRNA [23,24], and circRNA [25,26]. Unfortunately, due to miRNAs primarily exerting direct influence on other RNA molecules or proteins, which may or may not coexist together with the miRNA of interest, the basic presence or absence of any given miRNA is not necessarily enough to diagnose CRC. This conundrum adds a layer of difficulty in attempting to understand the relationship of these miRNAs to GI pathologies resulting in many unclear, or even contradictory, connections between the disease state and miRNA across samples and studies. Thus, to avoid a cavalcade listing of any miRNAs statistically associated with CRC, this review focuses on known miRNA signatures found within the biofluids of CRC patients, that also have accompanying evidence-based mechanistic hypotheses which represent ideal candidates for the use of biomarkers as diagnostics and/or therapeutics.

\section{2. miRNAs and Colorectal Cancer}

miRNAs are short RNA molecules, only 21-25 nucleotides in length upon the completion of the processing of the stem-loop pre-miRNA via the endoribonucleases Drosha and Dicer into single-stranded mature miRNAs, which are bound by Argonaute proteins for delivery to sequence-specific sites [27]. The most well-established method of the action of mature miRNAs is that of the binding targeted mRNAs through a nucleotide base pair complementarity between the miRNAs seed sequence (nucleotides $2-8$ from the $5^{\prime}$ end) and the targeted mRNA sequence, most commonly at the $3^{\prime}$ UTR or coding sequences leading to varied changes in the translation efficiency of the bound mRNA into a protein product [28-31]. A reduction in translation in the associated protein is most frequently observed, but increases in the associated protein expression do occur [32-34]. Additionally, strong evidence suggests the noncanonical binding of miRNAs occurs with functional effects as seen with miR-21 binding/activating Toll-like receptor proteins (TLR8) [35], as well as binding the lncRNA GAS5 [36], with both leading to pro-inflammatory signaling cascades, which are also found in CRC. Cataloging and correlating miRNAs associated with malignant tissue in order to uncover biomarkers has been an intense area of research for decades after it was found that miRNAs are better candidates for biomarker investigation than mRNAs [37-39]. Current literature suggests there are well over 230 miRNAs, 
and likely many more, associated with CRC, with some frequently appearing in various tissues/fluids/cells and others only rarely appearing [20,40-53]. Due to the seemingly boundless nature of connecting miRNAs to CRC tissue/biofluids/cells, the focus of this review is on some of the most well-established miRNAs, their pathways that lead to CRC, and observed levels in biofluids (Table 1, Figure 1) instead of an exhaustive inventory of all potential candidates. Many miRNAs are possible contenders for biomarking CRC in bodily fluids, as miRNAs affect numerous known pathways to malignancy as found below.

Table 1. Dysregulated miRNAs detected in noninvasive biofluids in CRC patient samples.

\begin{tabular}{|c|c|c|c|}
\hline miRNA & Biofluid Source & Levels in CRC & Reference \\
\hline \multirow{11}{*}{$\operatorname{miR}-21$} & Stool & Upregulated & [54] \\
\hline & Stool & Upregulated & [55] \\
\hline & Stool & Upregulated & [56] \\
\hline & Serum & Upregulated & {$[57]$} \\
\hline & Serum & Upregulated & [58] \\
\hline & Serum & Upregulated & [59] \\
\hline & Serum & Upregulated & [60] \\
\hline & Serum & Upregulated & [61] \\
\hline & Serum & Upregulated & [62] \\
\hline & Serum & Upregulated & [63] \\
\hline & Serum & Upregulated & [64] \\
\hline \multirow{4}{*}{ miR-17 } & Serum & Upregulated & [65] \\
\hline & Serum & Upregulated & [66] \\
\hline & Serum & Upregulated & [67] \\
\hline & Serum & Upregulated & {$[62]$} \\
\hline \multirow{3}{*}{$\operatorname{miR}-18 a$} & Plasma & Downregulated & [68] \\
\hline & Serum & Upregulated & [69] \\
\hline & Serum & Upregulated & [70] \\
\hline \multirow{9}{*}{ miR-19a } & Serum & Upregulated & [65] \\
\hline & Serum & Upregulated & [71] \\
\hline & Serum & Upregulated & [43] \\
\hline & Serum & Upregulated & [72] \\
\hline & Serum & Upregulated & [73] \\
\hline & Serum & Upregulated & [74] \\
\hline & Serum & Upregulated & [61] \\
\hline & Serum & Upregulated & [75] \\
\hline & Serum & Upregulated & [76] \\
\hline \multirow{5}{*}{ miR-20a } & Serum & Downregulated & [77] \\
\hline & Serum & Upregulated & [78] \\
\hline & Serum & Upregulated & [62] \\
\hline & Serum & Upregulated & [65] \\
\hline & Serum & Upregulated & [74] \\
\hline miR-19b & Serum & Upregulated & {$[43]$} \\
\hline \multirow{10}{*}{$\operatorname{miR}-92 a$} & Plasma & Upregulated & [79] \\
\hline & Stool & Upregulated & [54] \\
\hline & Serum & Upregulated & [75] \\
\hline & Serum & Upregulated & [80] \\
\hline & Serum & Upregulated & [63] \\
\hline & Serum & Upregulated & [81] \\
\hline & Serum & Upregulated & [82] \\
\hline & Serum & Upregulated & [83] \\
\hline & Serum & Upregulated & [84] \\
\hline & Serum & Downregulated & [84] \\
\hline
\end{tabular}


Table 1. Cont.

\begin{tabular}{|c|c|c|c|}
\hline miRNA & Biofluid Source & Levels in CRC & Reference \\
\hline \multirow{5}{*}{ miR-143 } & Plasma & Downregulated & [85] \\
\hline & Serum & Downregulated & [74] \\
\hline & Serum & Downregulated & [86] \\
\hline & Serum & Upregulated & [87] \\
\hline & Serum & No Significant Change & {$[84]$} \\
\hline \multirow{6}{*}{ miR-145 } & Plasma & Downregulated & [85] \\
\hline & Serum & Downregulated & [88] \\
\hline & Serum & Downregulated & [74] \\
\hline & Serum & Downregulated & [86] \\
\hline & Serum & No Significant Change & [84] \\
\hline & Serum & Downregulated & [66] \\
\hline \multirow{9}{*}{$\operatorname{miR}-203$} & Plasma & Upregulated & [89] \\
\hline & Serum & Downregulated & [84] \\
\hline & Serum & Upregulated & {$[90]$} \\
\hline & Serum & Upregulated & [91] \\
\hline & Serum & Downregulated & [92] \\
\hline & Serum & Upregulated & [93] \\
\hline & Serum & Upregulated & [94] \\
\hline & Serum & Upregulated & [95] \\
\hline & Serum & Upregulated & [96] \\
\hline miR-200a & None Reported & & \\
\hline $\mathrm{miR}-200 \mathrm{~b}$ & Plasma & Upregulated & [89] \\
\hline \multirow{6}{*}{ miR-200c } & Serum & Upregulated & [97] \\
\hline & Serum & Downregulated & [86] \\
\hline & Serum & Upregulated & [98] \\
\hline & Serum & Upregulated & [99] \\
\hline & Serum & Upregulated & [100] \\
\hline & Serum & Upregulated & [101] \\
\hline \multirow{4}{*}{ miR-141 } & Plasma & Upregulated & [89] \\
\hline & Serum & Upregulated & [98] \\
\hline & Serum & Upregulated & [99] \\
\hline & Serum & Upregulated & [101] \\
\hline $\mathrm{miR}-429$ & Serum & Upregulated & [102] \\
\hline \multirow{4}{*}{$\operatorname{miR}-135 a$} & Stool & Upregulated & [103] \\
\hline & Stool & Upregulated & [104] \\
\hline & Serum & Upregulated & [105] \\
\hline & Serum & Downregulated & [106] \\
\hline \multirow{3}{*}{$\operatorname{miR}-135 b$} & Stool & Upregulated & [107] \\
\hline & Stool & Upregulated & [108] \\
\hline & Serum & Upregulated & [109] \\
\hline \multirow{3}{*}{ miR-96 } & Plasma & Upregulated & [89] \\
\hline & Serum & Upregulated & [110] \\
\hline & Serum & No Significant Change & [69] \\
\hline \multirow{2}{*}{$\operatorname{miR}-183$} & Serum & Upregulated & [111] \\
\hline & Serum & Upregulated & [112] \\
\hline \multirow{6}{*}{$\operatorname{miR}-150$} & Serum & Downregulated & [113] \\
\hline & Serum & Upregulated & [74] \\
\hline & Serum & Downregulated & [114] \\
\hline & Serum & Downregulated & [115] \\
\hline & Serum & Upregulated & [116] \\
\hline & Serum & Downregulated & [64] \\
\hline \multirow{2}{*}{ miR-195 } & Plasma & Downregulated & [117] \\
\hline & Serum & Downregulated & [118] \\
\hline
\end{tabular}




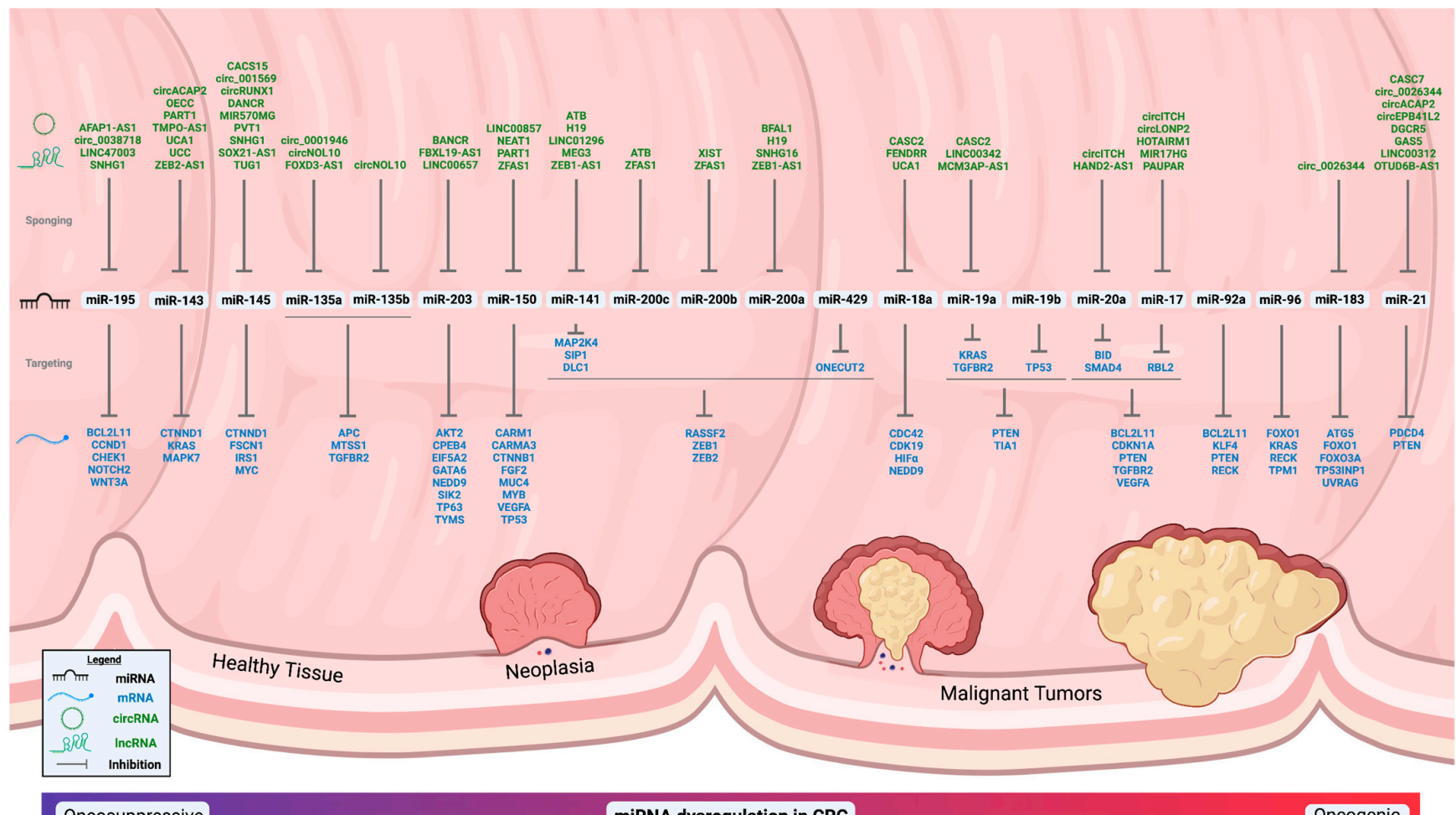

Figure 1. Dynamic relationships between miRNAs and ceRNAs and their connection to CRC. The miRNAs are listed in general/relative order of oncosuppressive to oncogenic in CRC from left to right with miRNA with dual natures being more central. All miRNAs, "sponging" ceRNAs (circRNA and lncRNA), and mRNAs listed have references cited within the main text and/or tables.

\section{1. $m i R-21$}

The MIR21 gene is located on chromosome 17, and was one of the first miRNAs found whose expression was positively associated with cancers, specifically hepatocellular and breast, via microarray [119-121], and is naturally highly expressed in immune cells (monocytes, macrophages, and dendritic cells) [122,123]. In fact, miR-21 has been found to be related to at least 29 disease conditions, leading to controversy on using miR-21 as a viable biomarker for specific diseases [124]. The global knockout of miR-21 does not appear to cause any phenotypic pathologies outside of elevated levels of some of its target genes in specific cell types [125]. Genomically, MIR21 is found within the VMP1 locus whose protein product is vital in maintaining cell-to-cell connections and the loss of its expression can lead to aggressive colorectal cancer [126,127]. Recently, it was found that miR-21 indirectly represses the expression of VMP1 through the inhibition of miR-21's known tumor suppressing target, PTEN, creating a negative feedback loop on VMP1 with increasing miR-21 levels [128]. The canonical pathway for miR-21-induced oncogenesis is through to be the direct repression of various well-known tumor suppressor genes, including PTEN [120,129] and PDCD4 [130,131], which activate cyclin-dependent kinases, c-MYC, and PI3K/AKT/mTOR pathways, which results in an increased invasion and metastasis $[10,125,132-134]$. MiR-21 also induces the increased expression of anti-apoptotic proteins such as BCL2 [121,135], and regulates more than twenty-five other known targets [136]. An analysis of resected colonic tissue confirmed the inverse relationship of miR-21 and PDCD4 in colorectal tumors, and their comparative expression levels can predict metastasis $[137,138]$. In addition to canonical pathways in CRC, miR-21 is known to bind and activate TLR8 protein [35], as well as binding and inhibiting the anti-inflammatory lncRNA GAS5 [36]. Furthermore, miR-21 levels have consistently been shown to be elevated in both the serum $[57,58,60,63,84]$ and fecal $[55,56]$ samples of CRC patients. MiR-21 
is implicated in several unique disease states and, thus, the use of its presence alone as an indicator for CRC is likely only a small piece of future miRNA biomarkers for CRC when combined with the expression levels of other ncRNAs and mRNA targets found in CRC patients.

\section{2. $m i R-17 / 92$ Cluster}

The miR-17/92a cluster is found within the third intron of the C13ORF25 locus on chromosome 13, contains miR-17, miR-18a, miR-19a, miR-20a, miR-19b, and miR-92a, and was initially found as a polycistronic and oncogenic lncRNA (MIR17HG) in lung cancer cells $[139,140]$. Every member of the miR-17/92 cluster has been found to be associated with either CRC tissue or plasma/serum [68,141-143]. The seed sequences of many of these mature miRNAs are redundant and found in other mature miRNAs. Each miRNA in the miR-17/92 has at least one redundant miRNA from within the miR-17/92a locus or within the miR-106a/363 or miR-106b/25 locus [140]. The deletion of the entire miR-17/92 cluster results in embryos of reduced size, which are fatal immediately after birth and the dual deletion of miR-17/92a and miR-106b/25 causes embryonic lethality, while the singular deletion of either the miR-106b/25 or miR-106a/363 cluster (or their combined ablation) has not produced a similar phenotype [144]. In general, the functional duality of miRNAs being both essential to development and oncogenesis is well-established, as they are both growth-promoting states [145]. In humans, the germline hemizygous deletion of miR-17/92 results in patients with type 2 Feingold syndrome [146]. These results emphasize that the essential nature of the miR-17/92 cluster cannot be rescued with seed sequence redundancy found in other miRNAs at other loci, further implying the importance of noncanonical cellular influence. Similar to many miRNAs, the miRNAs in the miR-17/92 cluster produce their oncogenic effect on several known pathways. In CRC tissue, miR-17 downregulates RBL2, leading to carcinogenic Wnt/ß-catenin induction [147], but has also shown the potential inhibition of colorectal cancer invasiveness when used in isolation [148]. Levels of miR-18a were found to be elevated in the serum of CRC patients and, thus, are a potential biomarker [69], while the application of isolated miR-18a inhibits CRC cell growth through the indirect regulation of the PI3K/AKT pathway [149] and has the potential to be sponged by the tumor-suppressing lncRNA CASC2 [150]. Similar to miR-21, miR-19a directly inhibits the tumor suppressor PTEN [151,152], as well as TIA1 [153], and can be predictive of the effectiveness of chemotherapeutic interventions on CRC [72,152], all while isolated miR-19a seemingly inhibits CRC angiogenesis via KRAS reduction [154]. Both miR-19a and miR-19b share identical seed sequences and miR-19b is also known to canonically inhibit PTEN expression [155,156], yet only miR-19b has been shown to inhibit tumor suppressor TP53 [157], further underscoring the effect of noncanonical miRNA influence. MiR-19b has already been indicated as a putative serum/plasma biomarker for other diseases, including lung cancer [158,159] and diabetic cardiomyopathy [160]. Similar to miR-21 and miR-19a, miR-92a activates the PI3K/AKT cell cycle pathway via PTEN inhibition, as well as activating Wnt/ß-catenin signaling, promoting carcinogenic development $[59,161,162]$ and downregulating the tumor suppressors RECK and KLF4 [163,164]. Both miR-17 and miR-20a share an identical seed sequence and, therefore, share many similar confirmed targets in CRC (BCL2L11, CDKN1A, PTEN, TGFBR2, and VEGFA) [143,165], while also having individualized targets as seen with miR-17 and RBL2 and miR-20a with BID and SMAD4 [78,166], stressing a non-seed sequence-based influence. MiR-92a has already been put forward as a marker of CRC in both serum/plasma [63,80,81] and stool samples [54,167] and whose overexpression is a recognized marker of poor prognosis in CRC tissue [168]. Many studies point to dysregulated miRNAs, including the miR-17/92 cluster, as a predictor of chemotherapy efficacy in CRC patients [152,169,170]. Within the miR-17/92 cluster, there are contradictory results between studies that could be attributable to many issues, including, but not limited to, differences in the cellular context [165], the use of miRNAs in isolation $[148,149,154]$ as opposed to the endogenous polycistronic expression of MIR17HG which increases CRC invasiveness [171], or structural components of pri-miR-19/72 itself that allow for the autoregulation of expression between each individual miRNA within the cluster [172-174]. 
As with miR-21, the miR-17/92 cluster is intimately tied to CRC at various levels of expression and continues to be an intense and promising area of study for biomarking CRC.

\section{3. $m i R-143$ and $m i R-145$}

Both miR-143 and miR-145 have different seed sequences and are found on chromosome 5 within the lncRNA CARMN locus [175], with miR-143 being slightly upstream of miR-145 and both under the control of the same SRF/MYOCD/NKX2.5 enhancer region [33]. The complete ablation of miR-143/145 results in the defective development of smooth muscle and aortic tissue [176]. While miR-21 and the miR-17/92 cluster are generally associated to be oncogenic in nature, both miR-143 and miR-145 are considered to be oncosuppressive, specifically within CRC [177-179], by mainly acting on the p53 and RAS/MAPK oncogenic pathways [180]. Both miR-143 and miR-145 are also known to directly downregulate CTNND1, which is a vital piece of Wnt/B-catenin carcinogenesis [181,182]; thus, showing miR-143/145 are antioncogenic through multiple pathways. Originally thought to be highly expressed in intestinal epithelial cells, it was found that while miR-143/145 are vital to epithelial cell regeneration, their expression was overwhelmingly found in the mesenchyme [183,184]. The experimentally validated targets of miR-143 included reducing MAPK7 [185] and KRAS [177], both members of the RAS/MAPK signaling pathway. MiR-145 is known to canonically inhibit the well-recognized oncogene MYC [6], PI3K activator, IRS1 [186], and metastatic promoter FSCN1 [187]. A reduction in the antioncogenic effect of miR-143/145 can be further exacerbated by their sponging via ncRNAs [188-191]. The sequestration of miR-143/145 via ncRNA sponging adds to the notion that miRNA levels of expression are not absolute in their cellular or histological effects, as there is a need to consider the levels of other ncRNAs that may reduce or eliminate their efficacy. In isolation, reduced tissue levels of miR-143/145 seem to be a marker of CRC, and have been found to be a marker for large tumors [192], while not being diagnostic between clinical stages of malignancy [193]. A few studies, with lower-than-optimal patient numbers, have investigated fecal samples for levels of miR-143/145 and found a lowered expression in CRC patient samples [194,195], but further broader studies are required to confirm these results. In CRC patients, plasma/serum levels of miR-143/145 have been found to be upregulated $[98,196]$, downregulated [74,85,86], or insignificant when compared to control samples [84]. These contradictory findings suggest that a reduced miR-143/145 is likely only a possible indicator of the presence of abnormal colorectal growth. However, the combined analysis of observed miR143/145 levels, compared to known targets/sponges, as well as other known oncogenic ncRNAs may provide any avenue for more accurate conclusions of the relation between miR-143/145 and CRC.

\section{4. miR-200 Family}

The miR-200 family can be found across two chromosomes, with miR-200b, miR-200a, and miR-429 on chromosome 1 and miR-200c and miR-141 on chromosome 12 in the intergenic space between PTPN6 and PHB2. MiR-200a and miR-141 share identical seed sequences, while miR-200b, miR-200c, and miR-429 have the same seed sequence, with only a single letter difference between the two groups [197]. Early studies uncovered that canonical targets of the miR-200 family are ZEB1/ZEB2 transcripts [198,199], which are master regulators of the epithelial-mesenchymal transition (EMT) via the inhibition of E-cadherin expression $[200,201]$, and ZEB proteins have a reciprocally negative feedback loop with the miR-200 family [202]. The inter-regulatory relationship of the miR-200 family downregulating ZEB1/ZEB2 that allows for the continued transcription of E-cadherin, which inhibits EMT, is generally accepted as the main carcinogenic pathway downregulated by the miR-200 family, specifically in CRC [203]. However, miR-200c specifically can increase the ability of metastasized CRC cells to proliferate in the liver [204], and the miR200 family as a whole is oncogenic in some CRC cell lines [205], again emphasizing the temporal and site-specific nature of the consequences of miRNA activity. It is also known that the miR-200 family antagonizes tumor angiogenesis, as shown in several cancer models, through the targeting of the pro-inflammatory CXCL1 [206]. MiR-200 family expression 
can be seen as tumor-suppressive [198,207], while also promoting metastasis [99,208] and, thus, its relation to CRC is strong but ill-defined. Expanding on the tumor-suppressive nature of the miR-200 family, isolated miR-429 is known to suppress EMT through the downregulation of ONECUT2 [209]. MiR-141 on its own is also known to inhibit the translation of several tumor-suppressor genes [210-212]. As the miR-200 family is located at two distinct chromosomal locations, complete family in vivo knockout is difficult and has only very recently been accomplished in vitro with knockout cells showing increases in senescence and EMT signaling genes with similar expression patterns found in gastric cancer patient RNA-seq samples [213]. The abnormal regulation of the miR-200 family as a whole has been indicated as a marker for CRC in serum/plasma [208,214], and as individual miRNAs: miR-200a [215], miR-200b [89], miR-200c [86,97-101], miR-141 [89,98,99,101,216], and miR-429 [102]. Furthermore, elevated serum levels of miR-200c and miR-141 have been correlated with an increased CRC metastasis [97,99] and poor prognoses in CRC patients [97,99-101,216]. Lowered miR-200a and elevated miR-200b in serum show similar patterns of being correlated with poor outcomes in CRC patients [89,211]. Moreover, the effectiveness of the carcinogenic influence of each member of the miR-200 family can potentially be mitigated by other ncRNAs that competitively inhibit their actions through sponging [217-220]. As in the case of other miRNAs and CRC, the basic presence or absence of miR-200 family transcripts in the biofluids of CRC patients alone is not enough to be diagnostic and must be considered within a cellular and histological framework while also considering expression levels of other contextually relevant and impactful ncRNAs.

\section{5. $m i R-203$}

Within the genome, miR-203 is located intergenically between ASPG and KIF26A on chromosome 14. It first came to research prominence when it was found that its expression was high in colorectal adenocarcinomas compared to noncancerous tissue [221], yet other studies have found lowered miR-203 levels in similar CRC tissue [222,223]. Its expression is a key switch for the differentiation of basal skin epithelial cells by directly downregulating TP63 [224]. In this way, miR-203 acts as a tumor suppressor by directly inhibiting $\Delta \mathrm{Np63}$, which, when active, causes nuclear B-catenin accumulation $[225,226]$. The whole-body knockout of miR-203 does not cause any overall developmental differences, but does invoke an expansion of proliferating keratinocytes, most notably during embryonic development [227]. In CRC cell lines, miR-203 reduction is required to maintain the stemness quality of cancerous lines [223,228,229], including through the reduction in the overexpressed and known CRC marker, NEDD9 [230,231]. Increases in miR-203 in CRC cells have been shown to canonically inhibit the oncogenic expression of AKT2, SIK2, CPEB4, EIF5A2, and TYMS [92,228,232-235]. Similar to other miRNAs, miR-203's activity can be halted by means of sponging by ncRNAs, such as FBXL19-AS1 [236], BANCR [237], and LINC00657 [238]. Many studies into the serum/plasma levels of miR-203 in CRC patients have discovered that differential levels of miR-203 are most often an indicator of poor prognosis and increased metastasis usually marked by an increase in miR-203 [89-91,93-96], with some showing lowered levels [84,92]. A meta-analyses of 11 papers found a higher miR-203 expression in CRC tissue to be significant, and not in serum, but a combination of both serum and CRC tissue was predictive of a poor outcome [239]. Additionally, such as other miRNAs, miR-203 is known to increase chemosensitivity in CRC cells [232,235]. MiR203 detection could present as a valuable piece of the puzzle in properly biomarking CRC.

\section{6. miR-135 Family}

The miR-135 family is represented by miR-135a found just upstream of GLYCTK on chromosome 3, and miR-135b, contained within the genomic sequence of both the lncRNA BLACAT1 and the gene LEMD1 on chromosome 1. Both miR-135a and miR-135b share identical mature seed sequences and only one nucleotide difference in total. The miR-135 family was originally tagged as an oncogene by its targeting and downregulating of the tumor suppressor APC (with which miR-135b it has a reciprocally inhibitory rela- 
tionship [240]) in CRC, which regulates the Wnt/ß-catenin pathway [241,242] as well as priming pancreatic cancer cells for pro-carcinogenic metabolic conditions through PFK1 downregulation [243]. In a CRC-specific context, miR-135a downregulates a metastasis driver MTSS1 [244] and miR-135b downregulates TGFBR2 [245], which is functionally mutated in up to $90 \%$ of CRC cases [246]. The effects of miR-135 can be antagonized through lncRNA sponging within a CRC context through circNOL10 [247]. Several studies have concentrated on modified levels of miR-135 family members in stool, tissue, and serum. As expected with the oncogenic nature of miR-135, stool samples show an increase in miR-135 expression $[103,107]$ and even being predictive of later-stage (III-IV) cancer [104]. CRC tissue samples with an increased miR-135 family expression are indicative of poor prognosis and metastatic conditions [240,248-250]. Low serum levels of miR-135 have been correlated with CRC [106], while elevated levels have been able to elucidate differences between polyps and carcinomas [105], and, thus, the use of miR-135 as a serum biomarker has been controversial [111] and, thus, focusing on noninvasive fecal samples has been more productive and a better candidate for the detection of the miR-135 family.

\section{7. $m i R-96$ and $m i R-183$}

On chromosome 7, miR-96 is found in a cluster with miR-183 and upstream of NRF1. Research interest in miR-96/183-related pathologies and development began with discoveries that both miR-96 and miR-183 are vital to hair cell development and function in the inner ear [251,252], and increases in miR-96 and miR-183 are found within breast and lung cancer tissue while directly downregulating FOXO1 and FOXO3A [253-256], key tumor suppressors in the P13K/AKT pathway of carcinogenesis. The knockout of the miR-96/183 cluster causes increases in target SLC6A6, resulting in dysfunctional photoreception [257]. In vitro CRC experiments have shown that increases in miR-96 and miR-183 are associated with both an increased cell migration $[258,259]$ and invasiveness [260,261]. Alongside this oncogenic character, a high miR-96 and miR-183 expression has also shown to increase resistance to chemotherapy treatments such as oxaliplatin [262], 5-fluoruracil [110], and radiation treatments [263], extending their oncogenic nature. Within studies of CRC tumor tissue samples, miR-96 and miR-183 were found to be elevated in all but one study [248,264-267], and that study found that lowered tumor tissue levels of miR-96 entailed poor patient prognoses [268]. A handful of studies have interrogated miR-96 levels in serum/plasma and have found that high levels [89,110], low levels [269], and no significant association with CRC [69] have been observed despite the fact that high miR-96 serum levels have been tied to both hepatocellular [269] and lung cancers [270]. Serum levels of miR-183 are consistently high in CRC patients [111,112]. The incongruous results from miR-96 could possibly be due to the neutralization of the oncogenic effects of miR-96 through sponging as has been seen in cervical cancer (STXBP5-AS1) [271] and pancreatic ductal adenocarcinoma (TP53TG1) [272]. In this vein, circ_0026344, has recently been shown to abrogate the oncogenic nature of miR-183 in CRC cells [273]. The consideration of miR-96 and miR-183 as biomarkers and targets for CRC diagnosis and treatment should, therefore, always be considered within the context of other mitigating ncRNAs.

\section{8. $\operatorname{miR}-150$}

Just upstream of RPS11 on chromosome 19 is miR-150. Initial analyses of miR-150 found it to be vital to proper hematopoietic cell differentiation [274], specifically B cell maturation [275], through the downregulation of MYB, which was confirmed in CRC cells [276]. Unsurprisingly, the knockout of miR-150 results in B cell developmental difficulties coupled with obesity-related metabolic dysregulation [277]. In addition to downregulating MYB in CRC, miR-150 also directly lowers the expression of B-catenin [278], VEGFA [279], and a known marker of poor prognoses in CRC patients, MUC4 [280]. As miR-150 canonically downregulates over several oncogenic pathways, it is generally seen as a tumor suppressor in CRC. In contrast, miR-150 is seen as oncogenic in gastric cancer tissues by downregulating the pro-apoptotic genes P2X 7 [281] and EGR2 [282] with a single study showing increases in miR-150 in CRC tissue [283]. Resected tissue samples from CRC patients 
regularly show a significantly decreased expression of miR-150 when compared to both adenoma and healthy colonic tissue $[278,279,284]$, and these reduced quantities can be indicative of poor prognoses [285]. However, when miR-150 expression was measured within serum samples of CRC patients, there have been observations of both increases $[74,116]$ and decreases [64,113-115], yet again stressing the need for the analysis of miRNA levels within a context of known targets and other ncRNA inhibitors. In this regard, the growth-suppressing consequences of miR-150 expression in CRC can be arrested by means of sponging via the lncRNAs ZFAS1 [286] and PART1 [287]. The previous successes with detecting low levels of miR-150 in CRC patients' serum suggests that the continued study of miR-150 and its relation to CRC, and known sequestering inhibitors, in serum/plasma will continue to be a fruitful area of investigation.

\section{9. $\operatorname{miR}-195$}

While a member of the miR-15 precursor family based on an identical seed sequence, miR-195 resides away from other family members and is found on chromosome 17 within the genomic location of lncRNA MIR497HG, just upstream of the $3^{\prime}$ UTR of C17ORF49. Modified levels of miR-195 first became an area of research in cardiac studies as increased levels of miR-195 were found to cause cardiac hypertrophy [288], as well as regulating cell cycle checkpoints in cardiomyocytes by targeting CHEK1 [289]. In terms of cancer research, early studies found that miR-195 was downregulated in hepatocellular cancer tissue via microarray [290], and that miR-195 inhibited CCND1 translation in both hepatocellular and colorectal cell lines [291], halting the cell cycling necessary for carcinogenic progression. Recently, miR-195 has also been found to be important in the cellular maintenance of the blood-brain barrier [292]. In addition to inhibiting CHEK1 in CRC cells, miR-195 prevents WNT3A translation [293], which is known to activate the Wnt/ $\$$-catenin oncogenic signaling pathway in CRC cells [294]. MiR-195 also canonically inhibits NOTCH2 [295] and BCL2L11 [296] in CRC cells, providing more pathways of tumor suppression through preventing EMT and promoting apoptosis, respectively. Similar to in vitro studies, miR-195 is consistently downregulated miRNA in CRC tissue samples [117,295-301], and the addition of miR-195 makes CRC cells sensitized to currently used chemotherapy interventions such as 5-fluorouracil [298,302], doxorubicin [303], and radiation therapy [304]. Surprisingly few studies have focused on serum/plasma levels of miR-195 in CRC patients, but results have shown the expected lowered levels of miR-195 [117]. Just as observed with other CRC-associated miRNAs, the tumor-suppressing actions of miR-195 can be annulled when sequestered through sponging by highly expressed lncRNA/circRNAs, with all of them promoting CRC carcinogenesis and progression [305-308]. Being able to couple known miR-195 targets and sponges, with stably reduced miR-195 in CRC tissues insinuates that miR-195 is a ripe area of further research in CRC.

\section{Discussion}

miRNAs, ceRNAs, and Chemosensitivity in CRC: A War of Attrition

Once the ability for miRNAs to be sponged out of efficacy by other ceRNAs was found to be robust, this provided the incentive to construct synthetic ceRNAs as sponges for oncogenic miRNAs. Methodologies for the building of unique miRNA sponges with multiple seed target sites were quickly introduced [309]. In practice, these sponges have indeed been able to isolate oncogenic miRNAs such as that observed with miR-21 sponging in renal cancer [310], gastric cancer [311], glioblastomas [312], and esophageal carcinomas [313]. Sponging has also been shown to be a direct driver of metastasis in CRC by circHIPK3 isolating miR-7 [314]. Thus, sponging miRNAs, such as the presence of miRNAs themselves, can be both oncogenic and suppressive in CRC. One very interesting operation of miRNAs in CRC is the ability to either sensitize or desensitize tumor cells to established chemotherapies and, therefore, be predictive of patient outcomes [170]. Both increased miR-21 and miR-17/92 expressions are indicative of chemoresistant tumors [110,169], and, thus, utilizing either increased ceRNA or synthetic ncRNA sponges would be ideal in helping sensitize patients to previously resistant chemotherapy or 
radiation. In contrast, miRNAs such as miR-203, whose increased expression is correlated with chemotolerance in CRC [232,235], represent a ripe opportunity to be used as an adjuvant to make resistant CRC cells susceptible to previously ineffective treatments. These examples epitomize the possible capabilities of targeting miRNA and miRNA-affected pathways in CRC treatments.

Despite observed patterns, one of the most consistent features of biofluid-borne ncRNAs in CRC patients is that their levels are almost never entirely correlative with disease presence, stage of development, metastasis extent, or susceptibility to known treatments. The colon and rectum are incredibly dynamic environments that constantly respond to various environmental cues, nutritional input, hypoxic conditions, and microbial influence, both commensal and pathogenic. This regularly reactive state causes the rapidly modulable nature of RNA to be an ideal molecule for responding to these shifting settings. This can manifest in the inducible power of miRNAs to alter mRNA translation, as well as ceRNAs' ability to negate those same miRNAs' effect on mRNA through competitive sequestration. Early studies on miRNAs and CRC quickly focused on elucidating their relationship to effectors of known carcinogenic pathways, such as mRNAs involved in the Wnt/B-catenin, PI3K/AKT, p53/c-MYC, and MAPK/ERK pathways. More recent analyses have unveiled the capacity for ceRNAs to mitigate the influence of miRNAs in CRC (Table 2). Neither the isolated investigation of miRNA on mRNA, or ceRNA on miRNA influence would complete the carcinogenic picture due to their attritive relationships.

Table 2. Reported ceRNAs and targeted miRNAs in CRC.

\begin{tabular}{|c|c|c|}
\hline miRNA & ceRNA in CRC & Reference \\
\hline \multirow{8}{*}{ miR-21 } & CASC7 & [315] \\
\hline & circ_0026344 & [316] \\
\hline & circACAP2 & [317] \\
\hline & circEPB41L2 & [318] \\
\hline & DGCR5 & [319] \\
\hline & GAS5 & [36] \\
\hline & LINC00312 & [320] \\
\hline & OTUD6B-AS1 & [321] \\
\hline \multirow{5}{*}{$\operatorname{miR}-17$} & circITCH & [12] \\
\hline & circLONP2 & [322] \\
\hline & HOTAIRM1 & [11] \\
\hline & MIR17HG & [171] \\
\hline & PAUPAR & [323] \\
\hline \multirow{3}{*}{ miR-18a } & CASC2 & [150] \\
\hline & FENDRR & [324] \\
\hline & UCA1 & [325] \\
\hline \multirow{3}{*}{ miR-19a } & CASC2 & [326] \\
\hline & LINC00342 & [327] \\
\hline & MCM3AP-AS1 & [328] \\
\hline \multirow{2}{*}{ miR-20a } & circITCH & [12] \\
\hline & HAND2-AS1 & [329] \\
\hline miR-19b & None Reported & \\
\hline $\operatorname{miR}-92 a$ & None Reported & \\
\hline \multirow{7}{*}{ miR-143 } & circACAP2 & [330] \\
\hline & OECC & [331] \\
\hline & PART1 & [190] \\
\hline & TMPO-AS1 & [332] \\
\hline & UCA1 & [189] \\
\hline & UCC & [188] \\
\hline & ZEB2-AS1 & [333] \\
\hline
\end{tabular}


Table 2. Cont.

\begin{tabular}{|c|c|c|}
\hline miRNA & ceRNA in CRC & Reference \\
\hline \multirow{9}{*}{ miR-145 } & CACS15 & [334] \\
\hline & circ_001569 & [191] \\
\hline & circRUNX1 & [335] \\
\hline & DANCR & [336] \\
\hline & MIR570MG & [337] \\
\hline & PVT1 & [338] \\
\hline & SNHG1 & [339] \\
\hline & SOX2-AS1 & [340] \\
\hline & TUG1 & [341] \\
\hline \multirow{3}{*}{ miR-203 } & BANCR & [237] \\
\hline & FBXL19-AS1 & [236] \\
\hline & LINC00657 & [238] \\
\hline \multirow{4}{*}{ miR-200a } & BFAL1 & [342] \\
\hline & H19 & [217] \\
\hline & SNHG16 & [343] \\
\hline & ZEB1-AS1 & [344] \\
\hline \multirow[b]{2}{*}{ miR-200b } & XIST & [345] \\
\hline & ZFAS1 & [218] \\
\hline \multirow{2}{*}{ miR-200c } & ATB & [346] \\
\hline & ZFAS1 & [218] \\
\hline \multirow{5}{*}{ miR-141 } & ATB & [347] \\
\hline & H19 & [348] \\
\hline & LINC01296 & [349] \\
\hline & MEG3 & [350] \\
\hline & ZEB1-AS1 & [218] \\
\hline $\operatorname{miR}-429$ & None Reported & \\
\hline \multirow{3}{*}{ miR-135a } & circ_0001946 & [351] \\
\hline & circNOL10 & [247] \\
\hline & FOXD3-AS1 & [352] \\
\hline miR-135b & circNOL10 & [247] \\
\hline $\operatorname{miR}-96$ & None Reported & \\
\hline miR-183 & circ_0026344 & [273] \\
\hline \multirow{4}{*}{$\operatorname{miR}-150$} & LINC00857 & [353] \\
\hline & NEAT1 & [354] \\
\hline & PART1 & [287] \\
\hline & ZFAS1 & [286] \\
\hline \multirow{4}{*}{ miR-195 } & AFAP-AS1 & [308] \\
\hline & circ_0038718 & [307] \\
\hline & LINC00473 & [306] \\
\hline & SNHG1 & [305] \\
\hline
\end{tabular}

The molecular CRC environment becomes further complicated as modifications to miRNA and ceRNA are known to alter their effect such as A-to-I editing [355] or m6A methylation [356]. This struggle between mRNA, miRNA, and ceRNAs over the carcinogenic capacity within CRC tumors demands the need for a more comprehensive review of the overall RNA influence in personalized CRC diagnosis and treatment. The main cytological affectations of miRNAs cannot be fully explained except in light of taking downstream targets into account. For example, circACAP2 is capable of sponging both oncogenic miR-21 [317] and suppressive miR-143 [330] and, therefore, circACAP2 in isolation could be considered carcinogenic or suppressive in relation to the sequestration of miR-21 or miR-143 in CRC. Thus, the vital examinations of interactive miRNA/ceRNA networks within a CRC context are becoming more necessary and prevalent [357-359], 
including studying the epigenetic regulation of miRNA/ceRNA expression [360], instead of focusing on individual cases of ceRNA/miRNA/mRNA interaction in order to provide a more thorough exploration of their collective effect on CRC. These examinations take a wider view of the interactions of multiple RNA species as they operate as a collective axis instead of concentrating on individual RNA species and allow for more personalized medical strategies [361]. Preliminary patterns of ceRNA-miRNA-mRNA networks in CRC samples are beginning to be discovered and provide a better framework for understanding the heterogenous CRC environment [357,362,363], and should be used as templates for the integrative ncRNA analysis in CRC patients. Figure 1 summarizes ceRNA-miRNA-mRNA networks in CRC, in which oncogenic or tumor suppressive miRNAs are dysregulated. The dysregulated miRNAs and ceRNAs can be potentially developed as biomarkers in the diagnosis of CRC as well as therapeutic targets to treat the disease. Continued work into personalized ncRNA-based diagnoses/treatments for the multifaceted and insidious nature of CRC could provide promising new avenues of prevention, diagnosis, and treatment.

Author Contributions: B.G.J. drafted and wrote the original manuscript draft, tables, and figures with intellectual guidance and instruction from S.R. S.R. completed final composition, edits, and design of the figures for the manuscript. All authors have read and agreed to the published version of the manuscript.

Funding: This review received no external funding.

Acknowledgments: Figure 1 adapted from "Benign and Malignant Colon Cancer" template, by BioRender.com (2022). Retrieved from https://app.biorender.com/biorender-templates on 7 January 2022.

Conflicts of Interest: The authors declare no conflict of interest.

\section{References}

1. Nigro, J.M.; Cho, K.R.; Fearon, E.R.; Kern, S.E.; Ruppert, J.M.; Oliner, J.D.; Kinzler, K.W.; Vogelstein, B. Scrambled exons. Cell 1991, 64, 607-613. [CrossRef]

2. Calin, G.A.; Liu, C.; Ferracin, M.; Hyslop, T.; Spizzo, R.; Sevignani, C.; Fabbri, M.; Cimmino, A.; Lee, E.J.; Wojcik, S.E.; et al. Ultraconserved Regions Encoding ncRNAs Are Altered in Human Leukemias and Carcinomas. Cancer Cell 2007, 12, 215-229. [CrossRef] [PubMed]

3. Calin, G.A.; Dumitru, C.D.; Shimizu, M.; Bichi, R.; Zupo, S.; Noch, E.; Aldler, H.; Rattan, S.; Keating, M.; Rai, K.; et al. Frequent deletions and down-regulation of micro-RNA genes miR15 and miR16 at 13q14 in chronic lymphocytic leukemia. Proc. Natl. Acad. Sci. USA 2002, 99, 15524-15529. [CrossRef] [PubMed]

4. Kristensen, L.S.; Hansen, T.B.; Venø, M.T.; Kjems, J. Circular RNAs in cancer: Opportunities and challenges in the field. Oncogene 2018, 37, 555-565. [CrossRef]

5. Takaoka, Y.; Shimizu, Y.; Hasegawa, H.; Ouchi, Y.; Qiao, S.; Nagahara, M.; Ichihara, M.; Lee, J.D.; Adachi, K.; Hamaguchi, M.; et al. Forced expression of miR-143 represses ERK5/c-Myc and p68/p72 signaling in concert with miR-145 in gut tumors of Apcmin mice. PLOS ONE 2012, 7, e42137. [CrossRef]

6. Sachdeva, M.; Zhu, S.; Wu, F.; Wu, H.; Walia, V.; Kumar, S.; Elble, R.; Watabe, K.; Mo, Y.-Y. p53 represses c-Myc through induction of the tumor suppressor miR-145. Proc. Natl. Acad. Sci. USA 2009, 106, 3207-3212. [CrossRef]

7. Pan, H.; Li, T.; Jiang, Y.; Pan, C.; Ding, Y.; Huang, Z.; Yu, H.; Kong, D. Overexpression of Circular RNA ciRS-7 Abrogates the Tumor Suppressive Effect of miR-7 on Gastric Cancer via PTEN/PI3K/AKT Signaling Pathway. J. Cell. Biochem. 2018, 119, 440-446. [CrossRef] [PubMed]

8. $\quad$ Fang, Y.; Xue, J.-L.; Shen, Q.; Chen, J.; Tian, L. MicroRNA-7 inhibits tumor growth and metastasis by targeting the phosphoinositide 3-kinase/Akt pathway in hepatocellular carcinoma. Hepatology 2012, 55, 1852-1862. [CrossRef]

9. Kino, T.; Hurt, D.E.; Ichijo, T.; Nader, N.; Chrousos, G.P. Noncoding RNA Gas5 Is a Growth Arrest- and Starvation-Associated Repressor of the Glucocorticoid Receptor. Sci. Signal. 2010, 3, 1-16. [CrossRef]

10. Pickard, M.; Williams, G. Molecular and Cellular Mechanisms of Action of Tumour Suppressor GAS5 LncRNA. Genes 2015, 6, 484-499. [CrossRef]

11. Ren, T.; Hou, J.; Liu, C.; Shan, F.; Xiong, X.; Qin, A.; Chen, J.; Ren, W. The long non-coding RNA HOTAIRM1 suppresses cell progression via sponging endogenous miR-17-5p/ B-cell translocation gene 3 (BTG3) axis in 5-fluorouracil resistant colorectal cancer cells. Biomed. Pharmacother. 2019, 117, 109171. [CrossRef]

12. Huang, G.; Zhu, H.; Shi, Y.; Wu, W.; Cai, H.; Chen, X. cir-ITCH Plays an Inhibitory Role in Colorectal Cancer by Regulating the Wnt/ $\beta$-Catenin Pathway. PLoS ONE 2015, 10, e0131225. [CrossRef] [PubMed]

13. Huels, D.J.; Sansom, O.J. Stem vs. non-stem cell origin of colorectal cancer. Br. J. Cancer 2015, 113, 1-5. [CrossRef] [PubMed] 
14. Blanpain, C. Tracing the cellular origin of cancer. Nat. Cell Biol. 2013, 15, 126-134. [CrossRef] [PubMed]

15. Mármol, I.; Sánchez-de-Diego, C.; Dieste, A.P.; Cerrada, E.; Yoldi, M.J.R. Colorectal carcinoma: A general overview and future perspectives in colorectal cancer. Int. J. Mol. Sci. 2017, 18, 197. [CrossRef] [PubMed]

16. Zauber, A.G.; Winawer, S.J.; O’Brien, M.J.; Lansdorp-Vogelaar, I.; van Ballegooijen, M.; Hankey, B.F.; Shi, W.; Bond, J.H.; Schapiro, M.; Panish, J.F.; et al. Colonoscopic Polypectomy and Long-Term Prevention of Colorectal-Cancer Deaths. N. Engl. J. Med. 2012, 366, 687-696. [CrossRef]

17. Van Dam, J. Prevention of Colorectal Cancer by Endoscopic Polypectomy. Ann. Intern. Med. 1995, 123, 949. [CrossRef] [PubMed]

18. Baxter, N.N.; Goldwasser, M.A.; Paszat, L.F.; Saskin, R.; Urbach, D.R.; Rabeneck, L. Association of colonoscopy and death from colorectal cancer. Ann. Intern. Med. 2009, 150, 1-8. [CrossRef]

19. Baran, B.; Mert Ozupek, N.; Yerli Tetik, N.; Acar, E.; Bekcioglu, O.; Baskin, Y. Difference Between Left-Sided and Right-Sided Colorectal Cancer: A Focused Review of Literature. Gastroenterol. Res. 2018, 11, 264-273. [CrossRef]

20. Luo, X.; Burwinkel, B.; Tao, S.; Brenner, H. MicroRNA signatures: Novel biomarker for colorectal cancer? Cancer Epidemiol. Biomarkers Prev. 2011, 20, 1272-1286. [CrossRef]

21. Wang, S.; Xiang, J.; Li, Z.; Lu, S.; Hu, J.; Gao, X.; Yu, L.; Wang, L.; Wang, J.; Wu, Y.; et al. A plasma microRNA panel for early detection of colorectal cancer. Int. J. Cancer 2015, 136, 152-161. [CrossRef] [PubMed]

22. Ahmed, F.E.; Jeffries, C.D.; Vos, P.W.; Flake, G.; Nuovo, G.J.; Sinar, D.R.; Naziri, W.; Marcuard, S.P. Diagnostic microRNA markers for screening sporadic human colon cancer and active ulcerative colitis in stool and tissue. Cancer Genom. Proteom. 2009, 6, 281-295.

23. Fan, Y.-H.; Ye, M.-H.; Wu, L.; Wu, M.-J.; Lu, S.-G.; Zhu, X.-G. BRAF-activated lncRNA predicts gastrointestinal cancer patient prognosis: A meta-analysis. Oncotarget 2017, 8, 6295-6303. [CrossRef]

24. Xu, W.; Zhou, G.; Wang, H.; Liu, Y.; Chen, B.; Chen, W.; Lin, C.; Wu, S.; Gong, A.; Xu, M. Circulating lncRNA SNHG11 as a novel biomarker for early diagnosis and prognosis of colorectal cancer. Int. J. Cancer 2020, 146, 2901-2912. [CrossRef]

25. Wang, Y.; Li, Z.; Xu, S.; Guo, J. Novel potential tumor biomarkers: Circular RNAs and exosomal circular RNAs in gastrointestinal malignancies. J. Clin. Lab. Anal. 2020, 34, e23359. [CrossRef]

26. Naeli, P.; Pourhanifeh, M.H.; Karimzadeh, M.R.; Shabaninejad, Z.; Movahedpour, A.; Tarrahimofrad, H.; Mirzaei, H.R.; Bafrani, H.H.; Savardashtaki, A.; Mirzaei, H.; et al. Circular RNAs and gastrointestinal cancers: Epigenetic regulators with a prognostic and therapeutic role. Crit. Rev. Oncol. Hematol. 2020, 145, 102854. [CrossRef]

27. Liu, J.; Carmell, M.A.; Rivas, F.V.; Marsden, C.G.; Thomson, J.M.; Song, J.-J.; Hammond, S.M.; Joshua-Tor, L.; Hannon, G.J Argonaute2 Is the Catalytic Engine of Mammalian RNAi. Science 2004, 305, 1437-1441. [CrossRef]

28. Lewis, B.P.; Shih, I.; Jones-Rhoades, M.W.; Bartel, D.P.; Burge, C.B. Prediction of Mammalian MicroRNA Targets. Cell 2003, 115, 787-798. [CrossRef]

29. Easow, G.; Teleman, A.A.; Cohen, S.M. Isolation of microRNA targets by miRNP immunopurification. RNA 2007, 13, 1198-1204 [CrossRef]

30. Baek, D.; Villén, J.; Shin, C.; Camargo, F.D.; Gygi, S.P.; Bartel, D.P. The impact of microRNAs on protein output. Nature 2008, 455, 64-71. [CrossRef]

31. Bartel, D.P. MicroRNAs: Target Recognition and Regulatory Functions. Cell 2009, 136, 215-233. [CrossRef] [PubMed]

32. Vasudevan, S.; Steitz, J.A. AU-Rich-Element-Mediated Upregulation of Translation by FXR1 and Argonaute 2. Cell 2007, 128, 1105-1118. [CrossRef]

33. Cordes, K.R.; Sheehy, N.T.; White, M.P.; Berry, E.C.; Morton, S.U.; Muth, A.N.; Lee, T.H.; Miano, J.M.; Ivey, K.N.; Srivastava, D MiR-145 and miR-143 regulate smooth muscle cell fate and plasticity. Nature 2009, 460, 705-710. [CrossRef] [PubMed]

34. Lin, C.-C.; Liu, L.-Z.; Addison, J.B.; Wonderlin, W.F.; Ivanov, A.V.; Ruppert, J.M. A KLF4-miRNA-206 Autoregulatory Feedback Loop Can Promote or Inhibit Protein Translation Depending upon Cell Context. Mol. Cell. Biol. 2011, 31, 2513-2527. [CrossRef] [PubMed]

35. Fabbri, M.; Paone, A.; Calore, F.; Galli, R.; Gaudio, E.; Santhanam, R.; Lovat, F.; Fadda, P.; Mao, C.; Nuovo, G.J.; et al. MicroRNAs bind to Toll-like receptors to induce prometastatic inflammatory response. Proc. Natl. Acad. Sci. USA 2012, 109. [CrossRef]

36. Zhang, Z.; Zhu, Z.; Watabe, K.; Zhang, X.; Bai, C.; Xu, M.; Wu, F.; Mo, Y.-Y. Negative regulation of lncRNA GAS5 by miR-21. Cell Death Differ. 2013, 20, 1558-1568. [CrossRef]

37. Lu, J.; Getz, G.; Miska, E.A.; Alvarez-Saavedra, E.; Lamb, J.; Peck, D.; Sweet-Cordero, A.; Ebert, B.L.; Mak, R.H.; Ferrando, A.A.; et al. MicroRNA expression profiles classify human cancers. Nature 2005, 435, 834-838. [CrossRef]

38. Volinia, S.; Calin, G.A.; Liu, C.G.; Ambs, S.; Cimmino, A.; Petrocca, F.; Visone, R.; Iorio, M.; Roldo, C.; Ferracin, M.; et al. A microRNA expression signature of human solid tumors defines cancer gene targets. Proc. Natl. Acad. Sci. USA 2006, 103, 2257-2261. [CrossRef]

39. Bandrés, E.; Cubedo, E.; Agirre, X.; Malumbres, R.; Zárate, R.; Ramirez, N.; Abajo, A.; Navarro, A.; Moreno, I.; Monzó, M.; et al. Identification by Real-time PCR of 13 mature microRNAs differentially expressed in colorectal cancer and non-tumoral tissues. Mol. Cancer 2006, 5, 1-10. [CrossRef]

40. Ren, A.; Dong, Y.; Tsoi, H.; Yu, J. Detection of miRNA as Non-Invasive Biomarkers of Colorectal Cancer. Int. J. Mol. Sci. 2015, 16, 2810-2823. [CrossRef]

41. Niu, L.; Yang, W.; Duan, L.; Wang, X.; Li, Y.; Xu, C.; Liu, C.; Zhang, Y.; Zhou, W.; Liu, J.; et al. Biological Implications and Clinical Potential of Metastasis-Related miRNA in Colorectal Cancer. Mol. Ther. Nucleic Acids 2021, 23, 42-54. [CrossRef] [PubMed] 
42. Vautrot, V.; Chanteloup, G.; Elmallah, M.; Cordonnier, M.; Aubin, F.; Garrido, C.; Gobbo, J. Exosomal miRNA: Small Molecules, Big Impact in Colorectal Cancer. J. Oncol. 2019, 2019, 1-18. [CrossRef] [PubMed]

43. Marcuello, M.; Duran-Sanchon, S.; Moreno, L.; Lozano, J.J.; Bujanda, L.; Castells, A.; Gironella, M. Analysis of A 6-Mirna Signature in Serum from Colorectal Cancer Screening Participants as Non-Invasive Biomarkers for Advanced Adenoma and Colorectal Cancer Detection. Cancers 2019, 11, 1542. [CrossRef] [PubMed]

44. Slattery, M.L.; Mullany, L.E.; Sakoda, L.; Samowitz, W.S.; Wolff, R.K.; Stevens, J.R.; Herrick, J.S. The NF-kB signalling pathway in colorectal cancer: Associations between dysregulated gene and miRNA expression. J. Cancer Res. Clin. Oncol. 2018, 144, 269-283. [CrossRef]

45. Tang, X.J.; Wang, W.; Hann, S.S. Interactions among lncRNAs, miRNAs and mRNA in colorectal cancer. Biochimie 2019, 163, 58-72. [CrossRef] [PubMed]

46. Zhang, H.; Zhu, M.; Shan, X.; Zhou, X.; Wang, T.; Zhang, J.; Tao, J.; Cheng, W.; Chen, G.; Li, J.; et al. A panel of seven-miRNA signature in plasma as potential biomarker for colorectal cancer diagnosis. Gene 2019, 687, 246-254. [CrossRef]

47. Rapado-González, Ó.; Majem, B.; Álvarez-Castro, A.; Díaz-Peña, R.; Abalo, A.; Suárez-Cabrera, L.; Gil-Moreno, A.; Santamaría, A.; López-López, R.; Muinelo-Romay, L.; et al. A Novel Saliva-Based miRNA Signature for Colorectal Cancer Diagnosis. J. Clin. Med. 2019, 8, 2029. [CrossRef]

48. Yang, L.; Belaguli, N.; Berger, D.H. MicroRNA and Colorectal Cancer. World J. Surg. 2009, 33, 638-646. [CrossRef]

49. Huang, X.; Zhu, X.; Yu, Y.; Zhu, W.; Jin, L.; Zhang, X.; Li, S.; Zou, P.; Xie, C.; Cui, R. Dissecting miRNA signature in colorectal cancer progression and metastasis. Cancer Lett. 2021, 501, 66-82. [CrossRef]

50. Falzone, L.; Scola, L.; Zanghì, A.; Biondi, A.; Di Cataldo, A.; Libra, M.; Candido, S. Integrated analysis of colorectal cancer microRNA datasets: Identification of microRNAs associated with tumor development. Aging 2018, 10, 1000-1014. [CrossRef]

51. Carter, J.V.; Roberts, H.L.; Pan, J.; Rice, J.D.; Burton, J.F.; Galbraith, N.J.; Eichenberger, M.R.; Jorden, J.; Deveaux, P.; Farmer, R.; et al. A Highly Predictive Model for Diagnosis of Colorectal Neoplasms Using Plasma MicroRNA. Ann. Surg. 2016, 264, 575-584. [CrossRef] [PubMed]

52. Lai, X.; Friedman, A. Exosomal microRNA concentrations in colorectal cancer: A mathematical model. J. Theor. Biol. 2017, 415, 70-83. [CrossRef] [PubMed]

53. Yang, G.; Zhang, Y.; Yang, J. A Five-microRNA Signature as Prognostic Biomarker in Colorectal Cancer by Bioinformatics Analysis. Front. Oncol. 2019, 9, 1207. [CrossRef] [PubMed]

54. Wu, C.W.; Ng, S.S.M.; Dong, Y.J.; Ng, S.C.; Leung, W.W.; Lee, C.W.; Wong, Y.N.; Chan, F.K.L.; Yu, J.; Sung, J.J.Y. Detection of miR-92a and miR-21 in stool samples as potential screening biomarkers for colorectal cancer and polyps. Gut 2012, 61, 739-745. [CrossRef] [PubMed]

55. Yau, T.O.; Tang, C.-M.; Harriss, E.K.; Dickins, B.; Polytarchou, C. Faecal microRNAs as a non-invasive tool in the diagnosis of colonic adenomas and colorectal cancer: A meta-analysis. Sci. Rep. 2019, 9, 9491. [CrossRef]

56. Link, A.; Balaguer, F.; Shen, Y.; Nagasaka, T.; Lozano, J.J.; Boland, C.R.; Goel, A. Fecal MicroRNAs as Novel Biomarkers for Colon Cancer Screening. Cancer Epidemiol. Biomarkers Prev. 2010, 19, 1766-1774. [CrossRef]

57. Toiyama, Y.; Takahashi, M.; Hur, K.; Nagasaka, T.; Tanaka, K.; Inoue, Y.; Kusunoki, M.; Boland, C.R.; Goel, A. Serum miR-21 as a diagnostic and prognostic biomarker in colorectal cancer. J. Natl. Cancer Inst. 2013, 105, 849-859. [CrossRef]

58. Yamada, A.; Horimatsu, T.; Okugawa, Y.; Nishida, N.; Honjo, H.; Ida, H.; Kou, T.; Kusaka, T.; Sasaki, Y.; Yagi, M.; et al. Serum MIR-21, MIR-29a, and MIR-125b are promising biomarkers for the early detection of colorectal neoplasia. Clin. Cancer Res. 2015, 21, 4234-4242. [CrossRef]

59. Zhang, G.; Zhou, H.; Xiao, H.; Liu, Z.; Tian, H.; Zhou, T. MicroRNA-92a Functions as an Oncogene in Colorectal Cancer by Targeting PTEN. Dig. Dis. Sci. 2014, 59, 98-107. [CrossRef]

60. Jin, X.-H.; Lu, S.; Wang, A.-F. Expression and clinical significance of miR-4516 and miR-21-5p in serum of patients with colorectal cancer. BMC Cancer 2020, 20, 241. [CrossRef]

61. Zhu, M.; Huang, Z.; Zhu, D.; Zhou, X.; Shan, X.; Qi, L.W.; Wu, L.; Cheng, W.; Zhu, J.; Zhang, L.; et al. A panel of microRNA signature in serum for colorectal cancer diagnosis. Oncotarget 2017, 8, 17081-17091. [CrossRef] [PubMed]

62. Gmerek, L.; Martyniak, K.; Horbacka, K.; Krokowicz, P.; Scierski, W.; Golusinski, P.; Golusinski, W.; Schneider, A.; Masternak, M.M. MicroRNA regulation in colorectal cancer tissue and serum. PLoS ONE 2019, 14, e0222013. [CrossRef] [PubMed]

63. Liu, G.-H.; Zhou, Z.-G.; Chen, R.; Wang, M.-J.; Zhou, B.; Li, Y.; Sun, X.-F. Serum miR-21 and miR-92a as biomarkers in the diagnosis and prognosis of colorectal cancer. Tumour Biol. 2013, 34, 2175-2181. [CrossRef] [PubMed]

64. Sarlinova, M.; Halasa, M.; Mistuna, D.; Musak, L.; Iliev, R.; Slaby, O.; Mazuchova, J.; Valentova, V.; Plank, L.; Halasova, E. Mir-21, mir-221 and mir-150 are deregulated in peripheral blood of patients with colorectal cancer. Anticancer Res. 2016, 36, 5449-5454. [CrossRef]

65. Zekri, A.R.N.; Youssef, A.S.E.D.; Lotfy, M.M.; Gabr, R.; Ahmed, O.S.; Nassar, A.; Hussein, N.; Omran, D.; Medhat, E.; Eid, S.; et al. Circulating serum miRNAs as diagnostic markers for colorectal cancer. PLoS ONE 2016, 11, e0154130. [CrossRef]

66. Li, J.; Liu, Y.; Wang, C.; Deng, T.; Liang, H.; Wang, Y.; Huang, D.; Fan, Q.; Wang, X.; Ning, T.; et al. Serum miRNA expression profile as a prognostic biomarker of stage II/III colorectal adenocarcinoma. Sci. Rep. 2015, 5, 1-13. [CrossRef]

67. Zhu, J.; Dong, H.; Zhang, Q.; Zhang, S. Combined assays for serum carcinoembryonic antigen and microRNA-17-3p offer improved diagnostic potential for stage I/II colon cancer. Mol. Clin. Oncol. 2015, 3, 1315-1318. [CrossRef] 
68. Zhang, G.-J.; Zhou, T.; Liu, Z.-L.; Tian, H.-P.; Xia, S.-S. Plasma miR-200c and miR-18a as potential biomarkers for the detection of colorectal carcinoma. Mol. Clin. Oncol. 2013, 1, 379-384. [CrossRef]

69. Vega, A.B.; Pericay, C.; Moya, I.; Ferrer, A.; Dotor, E.; Pisa, A.; Casalots, À.; Serra-Aracil, X.; Oliva, J.-C.; Ruiz, A.; et al. microRNA expression profile in stage III colorectal cancer: Circulating miR-18a and miR-29a as promising biomarkers. Oncol. Rep. 2013, 30, 320-326. [CrossRef]

70. Farace, C.; Pisano, A.; Griñan-Lison, C.; Solinas, G.; Jiménez, G.; Serra, M.; Carrillo, E.; Scognamillo, F.; Attene, F.; Montella, A.; et al. Deregulation of cancer-stem-cell-associated miRNAs in tissues and sera of colorectal cancer patients. Oncotarget 2020, 11, 116-130. [CrossRef]

71. Matsumura, T.; Sugimachi, K.; Iinuma, H.; Takahashi, Y.; Kurashige, J.; Sawada, G.; Ueda, M.; Uchi, R.; Ueo, H.; Takano, Y.; et al. Exosomal microRNA in serum is a novel biomarker of recurrence in human colorectal cancer. Br. J. Cancer 2015, 113, 275-281. [CrossRef]

72. Chen, Q.; Xia, H.W.; Ge, X.J.; Zhang, Y.C.; Tang, Q.L.; Bi, F. Serum miR-19a predicts resistance to FOLFOX chemotherapy in advanced colorectal cancer cases. Asian Pacific J. Cancer Prev. 2013, 14, 7421-7426. [CrossRef] [PubMed]

73. Yu, F.-B.; Sheng, J.; Yu, J.-M.; Liu, J.-H.; Qin, X.-X.; Mou, B. MiR-19a-3p regulates the Forkhead box F2-mediated Wnt/ $\beta$-catenin signaling pathway and affects the biological functions of colorectal cancer cells. World J. Gastroenterol. 2020, 26, 627-644. [CrossRef]

74. Maminezhad, H.; Ghanadian, S.; Pakravan, K.; Razmara, E.; Rouhollah, F.; Mossahebi-Mohammadi, M.; Babashah, S. A panel of six-circulating miRNA signature in serum and its potential diagnostic value in colorectal cancer. Life Sci. 2020, $258,118226$. [CrossRef] [PubMed]

75. Zheng, G.; Du, L.; Yang, X.; Zhang, X.; Wang, L.; Yang, Y.; Li, J.; Wang, C. Serum microRNA panel as biomarkers for early diagnosis of colorectal adenocarcinoma. Br. J. Cancer 2014, 111, 1985-1992. [CrossRef] [PubMed]

76. Dokhanchi, M.; Pakravan, K.; Zareian, S.; Hussen, B.M.; Farid, M.; Razmara, E.; Mossahebi-Mohammadi, M.; Cho, W.C.; Babashah, S. Colorectal cancer cell-derived extracellular vesicles transfer miR-221-3p to promote endothelial cell angiogenesis via targeting suppressor of cytokine signaling 3. Life Sci. 2021, 285, 119937. [CrossRef]

77. Yang, Q.; Wang, S.; Huang, J.; Xia, C.; Jin, H.; Fan, Y. Serum miR-20a and miR-486 are potential biomarkers for discriminating colorectal neoplasia: A pilot study. J. Cancer Res. Ther. 2018, 14, 1572. [CrossRef]

78. Huang, G.; Chen, X.; Cai, Y.; Wang, X.; Xing, C. miR-20a-directed regulation of BID is associated with the TRAIL sensitivity in colorectal cancer. Oncol. Rep. 2017, 37, 571-578. [CrossRef]

79. Huang, Z.; Huang, D.; Ni, S.; Peng, Z.; Sheng, W.; Du, X. Plasma microRNAs are promising novel biomarkers for early detection of colorectal cancer. Int. J. Cancer 2010, 127, 118-126. [CrossRef]

80. Shi, Y.; Liu, Z. Serum miR-92a-1 is a novel diagnostic biomarker for colorectal cancer. J. Cell. Mol. Med. 2020, $24,8363-8367$. [CrossRef]

81. Elshafei, A.; Shaker, O.; Abd El-motaal, O.; Salman, T. The expression profiling of serum miR-92a, miR-375, and miR-760 in colorectal cancer: An Egyptian study. Tumor Biol. 2017, 39, 101042831770576. [CrossRef] [PubMed]

82. Shiosaki, J.; Tiirikainen, M.; Peplowska, K.; Shaeffer, D.; Machida, M.; Sakamoto, K.; Takahashi, M.; Kojima, K.; Machi, J.; Bryant-Greenwood, P.; et al. Serum micro-RNA Identifies Early Stage Colorectal Cancer in a Multi-Ethnic Population. Asian Pacific J. Cancer Prev. 2020, 21, 3019-3026. [CrossRef] [PubMed]

83. Zheng, G.; Wang, H.; Zhang, X.; Yang, Y.; Wang, L.; Du, L.; Li, W.; Li, J.; Qu, A.; Liu, Y.; et al. Identification and validation of reference genes for qPCR detection of serum microRNAs in colorectal adenocarcinoma patients. PLoS ONE 2013, 8, e83025. [CrossRef] [PubMed]

84. Wang, J.; Huang, S.K.; Zhao, M.; Yang, M.; Zhong, J.L.; Gu, Y.Y.; Peng, H.; Che, Y.Q.; Huang, C.Z. Identification of a circulating microRNA signature for colorectal cancer detection. PLoS ONE 2014, 9, e87451. [CrossRef]

85. Luo, X.; Stock, C.; Burwinkel, B.; Brenner, H. Identification and Evaluation of Plasma MicroRNAs for Early Detection of Colorectal Cancer. PLoS ONE 2013, 8, e62880. [CrossRef] [PubMed]

86. Huang, G.; Wei, B.; Chen, Z.; Wang, J.; Zhao, L.; Peng, X.; Liu, K.; Lai, Y.; Ni, L. Identification of a four-microRNA panel in serum as promising biomarker for colorectal carcinoma detection. Biomark. Med. 2020, 14, 749-760. [CrossRef]

87. Hiyoshi, Y.; Akiyoshi, T.; Inoue, R.; Murofushi, K.; Yamamoto, N.; Fukunaga, Y.; Ueno, M.; Baba, H.; Mori, S.; Yamaguchi, T. Serum miR-143 levels predict the pathological response to neoadjuvant chemoradiotherapy in patients with locally advanced rectal cancer. Oncotarget 2017, 8, 79201-79211. [CrossRef]

88. Ramzy, I.; Hasaballah, M.; Marzaban, R.; Shaker, O.; Soliman, Z.A. Evaluation of microRNAs-29a, 92a and 145 in colorectal carcinoma as candidate diagnostic markers: An Egyptian pilot study. Clin. Res. Hepatol. Gastroenterol. 2015, 39, 508-515. [CrossRef]

89. Sun, Y.; Liu, Y.; Cogdell, D.; Calin, G.A.; Sun, B.; Kopetz, S.; Hamilton, S.R.; Zhang, W. Examining plasma microRNA markers for colorectal cancer at different stages. Oncotarget 2016, 7, 11434-11449. [CrossRef]

90. Kingham, T.P.; Nguyen, H.C.B.; Zheng, J.; Konstantinidis, I.T.; Sadot, E.; Shia, J.; Kuk, D.; Zhang, S.; Saltz, L.; D’ Angelica, M.I.; et al MicroRNA-203 predicts human survival after resection of colorectal liver metastasis. Oncotarget 2017, 8, 18821-18831. [CrossRef]

91. Takano, Y.; Masuda, T.; Iinuma, H.; Yamaguchi, R.; Sato, K.; Tobo, T.; Hirata, H.; Kuroda, Y.; Nambara, S.; Hayashi, N.; et al Circulating exosomal microRNA-203 is associated with metastasis possibly via inducing tumor-associated macrophages in colorectal cancer. Oncotarget 2017, 8, 78598-78613. [CrossRef] [PubMed] 
92. Deng, B.; Wang, B.; Fang, J.; Zhu, X.; Cao, Z.; Lin, Q.; Zhou, L.; Sun, X. MiRNA-203 suppresses cell proliferation, migration and invasion in colorectal cancer via targeting of EIF5A2. Sci. Rep. 2016, 6, 1-11. [CrossRef] [PubMed]

93. Hur, K.; Toiyama, Y.; Okugawa, Y.; Ide, S.; Imaoka, H.; Boland, C.R.; Goel, A. Circulating microRNA-203 predicts prognosis and metastasis in human colorectal cancer. Gut 2017, 66, 654-664. [CrossRef] [PubMed]

94. Peng, Q.; Shen, Y.; Zhao, P.; Cai, S.; Feng, Z.; Cheng, M.; Wu, Y.; Zhu, Y. Biomarker exploration of microRNA-203 as a promising substrate for predicting poor survival outcome in colorectal cancer. BMC Cancer 2020, 20, 1-14. [CrossRef] [PubMed]

95. Yuan, Z.; Baker, K.; Redman, M.W.; Wang, L.; Adams, S.V.; Yu, M.; Dickinson, B.; Makar, K.; Ulrich, N.; Böhm, J.; et al. Dynamic plasma microRNAs are biomarkers for prognosis and early detection of recurrence in colorectal cancer. Br. J. Cancer 2017, 117, 1202-1210. [CrossRef] [PubMed]

96. Nassar, F.J.; Msheik, Z.S.; Itani, M.M.; El Helou, R.; Hadla, R.; Kreidieh, F.; Bejjany, R.; Mukherji, D.; Shamseddine, A.; Nasr, R.R.; et al. Circulating mirna as biomarkers for colorectal cancer diagnosis and liver metastasis. Diagnostics 2021, 11, 341. [CrossRef] [PubMed]

97. Toiyama, Y.; Hur, K.; Tanaka, K.; Inoue, Y.; Kusunoki, M.; Boland, C.R.; Goel, A. Serum miR-200c Is a Novel Prognostic and Metastasis-Predictive Biomarker in Patients with Colorectal Cancer. Ann. Surg. 2014, 259, 735-743. [CrossRef]

98. Ardila, H.J.; Sanabria-Salas, M.C.; Meneses, X.; Rios, R.; Huertas-Salgado, A.; Serrano, M.L. Circulating miR-141-3p, miR-143-3p and miR-200c-3p are differentially expressed in colorectal cancer and advanced adenomas. Mol. Clin. Oncol. 2019, 11, 201-207. [CrossRef]

99. Ding, M.; Zhang, T.; Li, S.; Zhang, Y.; Qiu, Y.; Zhang, B. Correlation analysis between liver metastasis and serum levels of MIR-200 and MIR-141 in patients with colorectal cancer. Mol. Med. Rep. 2017, 16, 7791-7795. [CrossRef]

100. Tayel, S.I.; Fouda, E.A.M.; Gohar, S.F.; Elshayeb, E.I.; El-sayed, E.H.; El-kousy, S.M. Potential role of MicroRNA 200c gene expression in assessment of colorectal cancer. Arch. Biochem. Biophys. 2018, 647, 41-46. [CrossRef]

101. Santasusagna, S.; Moreno, I.; Navarro, A.; Martinez Rodenas, F.; Hernández, R.; Castellano, J.J.; Muñoz, C.; Monzo, M. Prognostic impact of miR-200 family members in plasma and exosomes from tumor-draining versus peripheral veins of colon cancer patients. Oncology 2018, 95, 309-318. [CrossRef] [PubMed]

102. Dong, S.J.; Cai, X.J.; Li, S.J. The clinical significance of MiR-429 as a predictive biomarker in colorectal cancer patients receiving 5-fluorouracil treatment. Med. Sci. Monit. 2016, 22, 3352-3361. [CrossRef]

103. Koga, Y.; Yasunaga, M.; Takahashi, A.; Kuroda, J.; Moriya, Y.; Akasu, T.; Fujita, S.; Yamamoto, S.; Baba, H.; Matsumura, Y. MicroRNA expression profiling of exfoliated colonocytes isolated from feces for colorectal cancer screening. Cancer Prev. Res. 2010, 3, 1435-1442. [CrossRef] [PubMed]

104. Li, L.; Wang, A.; Cai, M.; Tong, M.; Chen, F.; Huang, L. Identification of stool miR-135b-5p as a non-invasive diaognostic biomarker in later tumor stage of colorectal cancer. Life Sci. 2020, 260, 1-7. [CrossRef] [PubMed]

105. Wang, Q.; Zhang, H.; Shen, X.; Ju, S. Serum microRNA-135a-5p as an auxiliary diagnostic biomarker for colorectal cancer. Ann. Clin. Biochem. 2017, 54, 76-85. [CrossRef] [PubMed]

106. Zhou, X.; Yang, D.; Ding, X.; Xu, P. Clinical value of microRNA-135a and MMP-13 in colon cancer. Oncol. Lett. 2021, 22, 1-9. [CrossRef]

107. Wu, C.W.; Ng, S.C.; Dong, Y.; Tian, L.; Ng, S.S.M.; Leung, W.W.; Law, W.T.; Yau, T.O.; Chan, F.K.L.; Sung, J.J.Y.; et al. Identification of microrna-135b in stool as a potential noninvasive biomarker for colorectal cancer and adenoma. Clin. Cancer Res. 2014, 20, 2994-3002. [CrossRef]

108. Phua, L.C.; Chue, X.P.; Koh, P.K.; Cheah, P.Y.; Chan, E.C.Y.; Ho, H.K. Global fecal microRNA profiling in the identification of biomarkers for colorectal cancer screening among Asians. Oncol. Rep. 2014, 32, 97-104. [CrossRef]

109. Qin, Y.; Li, L.; Wang, F.; Zhou, X.; Liu, Y.; Yin, Y.; Qi, X. Knockdown of miR-135b sensitizes colorectal cancer cells to oxaliplatininduced apoptosis through increase of FOXO1. Cell. Physiol. Biochem. 2018, 48, 1627-1637. [CrossRef]

110. Jin, G.; Liu, Y.; Zhang, J.; Bian, Z.; Yao, S.; Fei, B.; Zhou, L.; Yin, Y.; Huang, Z. A panel of serum exosomal microRNAs as predictive markers for chemoresistance in advanced colorectal cancer. Cancer Chemother. Pharmacol. 2019, 84, 315-325. [CrossRef]

111. Faltejskova, P.; Bocanek, O.; Sachlova, M.; Svoboda, M.; Kiss, I.; Vyzula, R.; Slaby, O. Circulating miR-17-3p, miR-29a, miR-92a and miR-135b in serum: Evidence against their usage as biomarkers in colorectal cancer. Cancer Biomarkers 2012, 12, 199-204. [CrossRef] [PubMed]

112. Yuan, D.; Li, K.; Zhu, K.; Yan, R.; Dang, C. Plasma miR-183 predicts recurrence and prognosis in patients with colorectal cancer. Cancer Biol. Ther. 2015, 16, 268-275. [CrossRef] [PubMed]

113. Zhao, Y.J.; Song, X.; Niu, L.; Tang, Y.; Song, X.; Xie, L. Circulating exosomal mir-150-5p and mir-99b-5p as diagnostic biomarkers for colorectal cancer. Front. Oncol. 2019, 9, 1-10. [CrossRef]

114. Xiao, Y.; Zhong, J.; Zhong, B.; Huang, J.; Jiang, L.; Jiang, Y.; Yuan, J.; Sun, J.; Dai, L.; Yang, C.; et al. Exosomes as potential sources of biomarkers in colorectal cancer. Cancer Lett. 2020, 476, 13-22. [CrossRef]

115. Aherne, S.T.; Madden, S.F.; Hughes, D.J.; Pardini, B.; Naccarati, A.; Levy, M.; Vodicka, P.; Neary, P.; Dowling, P.; Clynes, M. Circulating miRNAs miR-34a and miR-150 associated with colorectal cancer progression. BMC Cancer 2015, 15, 1-13. [CrossRef]

116. Ogata-Kawata, H.; Izumiya, M.; Kurioka, D.; Honma, Y.; Yamada, Y.; Furuta, K.; Gunji, T.; Ohta, H.; Okamoto, H.; Sonoda, H.; et al. Circulating exosomal microRNAs as biomarkers of colon cancer. PLoS ONE 2014, 9, e92921. [CrossRef] 
117. Al-Sheikh, Y.A.; Ghneim, H.K.; Softa, K.I.; Al-Jobran, A.A.; Al-Obeed, O.; Mohamed, M.A.V.; Abdulla, M.; Aboul-Soud, M.A.M Expression profiling of selected microRNA signatures in plasma and tissues of Saudi colorectal cancer patients by qPCR. Oncol. Lett. 2016, 11, 1406-1412. [CrossRef] [PubMed]

118. Wada, Y.; Shimada, M.; Murano, T.; Takamaru, H.; Morine, Y.; Ikemoto, T.; Saito, Y.; Balaguer, F.; Bujanda, L.; Pellise, M.; et al. A Liquid Biopsy Assay for Noninvasive Identification of Lymph Node Metastases in T1 Colorectal Cancer. Gastroenterology 2021, 161, 151-162.e1. [CrossRef]

119. Iorio, M.V.; Ferracin, M.; Liu, C.G.; Veronese, A.; Spizzo, R.; Sabbioni, S.; Magri, E.; Pedriali, M.; Fabbri, M.; Campiglio, M.; et al MicroRNA gene expression deregulation in human breast cancer. Cancer Res. 2005, 65, 7065-7070. [CrossRef]

120. Meng, F.; Henson, R.; Wehbe-Janek, H.; Ghoshal, K.; Jacob, S.T.; Patel, T. MicroRNA-21 Regulates Expression of the PTEN Tumor Suppressor Gene in Human Hepatocellular Cancer. Gastroenterology 2007, 133, 647-658. [CrossRef]

121. Si, M.L.; Zhu, S.; Wu, H.; Lu, Z.; Wu, F.; Mo, Y.Y. miR-21-mediated tumor growth. Oncogene 2007, 26, 2799-2803. [CrossRef] [PubMed]

122. Kasashima, K.; Nakamura, Y.; Kozu, T. Altered expression profiles of microRNAs during TPA-induced differentiation of HL-60 cells. Biochem. Biophys. Res. Commun. 2004, 322, 403-410. [CrossRef] [PubMed]

123. Cekaite, L.; Clancy, T.; Sioud, M. Increased miR-21 expression during human monocyte differentiation into DCs. Front. Biosci. 2010, E2, 143. [CrossRef]

124. Jenike, A.E.; Halushka, M.K. miR-21: A non-specific biomarker of all maladies. Biomark. Res. 2021, 9, 18. [CrossRef]

125. Ma, X.; Kumar, M.; Choudhury, S.N.; Becker Buscaglia, L.E.; Barker, J.R.; Kanakamedala, K.; Liu, M.-F.; Li, Y. Loss of the miR-21 allele elevates the expression of its target genes and reduces tumorigenesis. Proc. Natl. Acad. Sci. USA 2011, 108, 10144-10149. [CrossRef]

126. Guo, X.-Z.; Ye, X.-L.; Xiao, W.-Z.; Wei, X.-N.; You, Q.-H.; Che, X.-H.; Cai, Y.-J.; Chen, F.; Yuan, H.; Liu, X.-J.; et al. Downregulation of VMP1 confers aggressive properties to colorectal cancer. Oncol. Rep. 2015, 34, 2557-2566. [CrossRef]

127. Sauermann, M.; Sahin, Ö.; Sültmann, H.; Hahne, F.; Blaszkiewicz, S.; Majety, M.; Zatloukal, K.; Füzesi, L.; Poustka, A.; Wiemann, S.; et al. Reduced expression of vacuole membrane protein 1 affects the invasion capacity of tumor cells. Oncogene 2008, 27, 1320-1326. [CrossRef]

128. Wang, C.; Peng, R.; Zeng, M.; Zhang, Z.; Liu, S.; Jiang, D.; Lu, Y.; Zou, F. An autoregulatory feedback loop of miR-21/VMP1 is responsible for the abnormal expression of miR-21 in colorectal cancer cells. Cell Death Dis. 2020, 11, 1067. [CrossRef]

129. Meng, F.; Henson, R.; Lang, M.; Wehbe, H.; Maheshwari, S.; Mendell, J.T.; Jiang, J.; Schmittgen, T.D.; Patel, T. Involvement of Human Micro-RNA in Growth and Response to Chemotherapy in Human Cholangiocarcinoma Cell Lines. Gastroenterology 2006, 130, 2113-2129. [CrossRef]

130. Asangani, I.A.; Rasheed, S.A.K.; Nikolova, D.A.; Leupold, J.H.; Colburn, N.H.; Post, S.; Allgayer, H. MicroRNA-21 (miR-21) post-transcriptionally downregulates tumor suppressor Pdcd4 and stimulates invasion, intravasation and metastasis in colorectal cancer. Oncogene 2008, 27, 2128-2136. [CrossRef]

131. Sheedy, F.J.; Palsson-McDermott, E.; Hennessy, E.J.; Martin, C.; O’Leary, J.J.; Ruan, Q.; Johnson, D.S.; Chen, Y.; O’Neill, L.A.J. Negative regulation of TLR4 via targeting of the proinflammatory tumor suppressor PDCD4 by the microRNA miR-21. Nat. Immunol. 2010, 11, 141-147. [CrossRef] [PubMed]

132. Wu, Y.; Song, Y.; Xiong, Y.; Wang, X.; Xu, K.; Han, B.; Bai, Y.; Li, L.; Zhang, Y.; Zhou, L. MicroRNA-21 (Mir-21) Promotes Cell Growth and Invasion by Repressing Tumor Suppressor PTEN in Colorectal Cancer. Cell. Physiol. Biochem. 2017, 43, 945-958. [CrossRef] [PubMed]

133. Long, J.; Yin, Y.; Guo, H.; Li, S.; Sun, Y.; Zeng, C.; Zhu, W. The mechanisms and clinical significance of PDCD4 in colorectal cancer Gene 2019, 680, 59-64. [CrossRef] [PubMed]

134. Xiong, B.; Cheng, Y.; Ma, L.; Zhang, C. MiR-21 regulates biological behavior through the PTEN/PI-3 K/Akt signaling pathway in human colorectal cancer cells. Int. J. Oncol. 2013, 42, 219-228. [CrossRef]

135. Shi, L.; Chen, J.; Yang, J.; Pan, T.; Zhang, S.; Wang, Z. MiR-21 protected human glioblastoma U87MG cells from chemotherapeutic drug temozolomide induced apoptosis by decreasing Bax/Bcl-2 ratio and caspase-3 activity. Brain Res. 2010, 1352, $255-264$. [CrossRef]

136. Buscaglia, L.E.B.; Li, Y. Apoptosis and the target genes of microRNA-21. Chin. J. Cancer 2011, 30, 371-380. [CrossRef]

137. Ferraro, A.; Kontos, C.K.; Boni, T.; Bantounas, I.; Siakouli, D.; Kosmidou, V.; Vlassi, M.; Spyridakis, Y.; Tsipras, I.; Zografos, G.; et al. Epigenetic regulation of miR-21 in colorectal cancer. Epigenetics 2014, 9, 129-141. [CrossRef]

138. Chang, K.H.; Miller, N.; Kheirelseid, E.A.H.; Ingoldsby, H.; Hennessy, E.; Curran, C.E.; Curran, S.; Smith, M.J.; Regan, M.; McAnena, O.J.; et al. MicroRNA-21 and PDCD4 expression in colorectal cancer. Eur. J. Surg. Oncol. 2011, 37, 597-603. [CrossRef]

139. Hayashita, Y.; Osada, H.; Tatematsu, Y.; Yamada, H.; Yanagisawa, K.; Tomida, S.; Yatabe, Y.; Kawahara, K.; Sekido, Y.; Takahashi, T. A Polycistronic MicroRNA Cluster, miR-17-92, Is Overexpressed in Human Lung Cancers and Enhances Cell Proliferation. Cancer Res. 2005, 65, 9628-9632. [CrossRef]

140. Mendell, J.T. miRiad Roles for the miR-17-92 Cluster in Development and Disease. Cell 2008, 133, 217-222. [CrossRef]

141. Diosdado, B.; Van De Wiel, M.A.; Terhaar Sive Droste, J.S.; Mongera, S.; Postma, C.; Meijerink, W.J.H.J.; Carvalho, B.; Meijer, G.A. MiR-17-92 cluster is associated with $13 \mathrm{q}$ gain and c-myc expression during colorectal adenoma to adenocarcinoma progression. Br. J. Cancer 2009, 101, 707-714. [CrossRef] 
142. Sun, R.; Liang, Y.; Yuan, F.; Nie, X.; Sun, H.; Wang, Y.; Yu, T.; Gao, L.; Zhang, L. Functional polymorphisms in the promoter region of miR-17-92 cluster are associated with a decreased risk of colorectal cancer. Oncotarget 2017, 8, 82531-82540. [CrossRef]

143. Humphreys, K.J.; Cobiac, L.; Le Leu, R.K.; Van der Hoek, M.B.; Michael, M.Z. Histone deacetylase inhibition in colorectal cancer cells reveals competing roles for members of the oncogenic miR-17-92 cluster. Mol. Carcinog. 2013, 52, 459-474. [CrossRef] [PubMed]

144. Ventura, A.; Young, A.G.; Winslow, M.M.; Lintault, L.; Meissner, A.; Erkeland, S.J.; Newman, J.; Bronson, R.T.; Crowley, D.; Stone, J.R.; et al. Targeted Deletion Reveals Essential and Overlapping Functions of the miR-17 92 Family of miRNA Clusters. Cell 2008, 132, 875-886. [CrossRef] [PubMed]

145. Lujambio, A.; Lowe, S.W. The microcosmos of cancer. Nature 2012, 482, 347-355. [CrossRef] [PubMed]

146. de Pontual, L.; Yao, E.; Callier, P.; Faivre, L.; Drouin, V.; Cariou, S.; Van Haeringen, A.; Geneviève, D.; Goldenberg, A.; Oufadem, M.; et al. Germline deletion of the miR-17 92 cluster causes skeletal and growth defects in humans. Nat. Genet. 2011, 43, 1026-1030. [CrossRef] [PubMed]

147. Ma, Y.; Zhang, P.; Wang, F.; Zhang, H.; Yang, Y.; Shi, C.; Xia, Y.; Peng, J.; Liu, W.; Yang, Z.; et al. Elevated oncofoetal miR-17-5p expression regulates colorectal cancer progression by repressing its target gene P130. Nat. Commun. 2012, 3, 1291. [CrossRef]

148. Ast, V.; Kordaß, T.; Oswald, M.; Kolte, A.; Eisel, D.; Osen, W.; Eichmüller, S.B.; Berndt, A.; König, R. MiR-192, miR-200c and miR-17 are fibroblast-mediated inhibitors of colorectal cancer invasion. Oncotarget 2018, 9, 35559-35580. [CrossRef]

149. Humphreys, K.J.; McKinnon, R.A.; Michael, M.Z. miR-18a Inhibits CDC42 and Plays a Tumour Suppressor Role in Colorectal Cancer Cells. PLoS ONE 2014, 9, e112288. [CrossRef]

150. Huang, G.; Wu, X.; Li, S.; Xu, X.; Zhu, H.; Chen, X. The long noncoding RNA CASC2 functions as a competing endogenous RNA by sponging miR-18a in colorectal cancer. Sci. Rep. 2016, 6, 1-11. [CrossRef]

151. Olive, V.; Bennett, M.J.; Walker, J.C.; Ma, C.; Jiang, I.; Cordon-Cardo, C.; Li, Q.-J.; Lowe, S.W.; Hannon, G.J.; He, L. miR-19 is a key oncogenic component of mir-17-92. Genes Dev. 2009, 23, 2839-2849. [CrossRef] [PubMed]

152. Zhang, Y.; Liu, X.; Zhang, J.; Xu, Y.; Shao, J.; Hu, Y.; Shu, P.; Cheng, H. Inhibition of miR-19a partially reversed the resistance of colorectal cancer to oxaliplatin via PTEN/PI3K/AKT pathway. Aging 2020, 12, 5640-5650. [CrossRef] [PubMed]

153. Liu, Y.; Liu, R.; Yang, F.; Cheng, R.; Chen, X.; Cui, S.; Gu, Y.; Sun, W.; You, C.; Liu, Z.; et al. miR-19a promotes colorectal cancer proliferation and migration by targeting TIA1. Mol. Cancer 2017, 16, 53. [CrossRef]

154. Chen, M.; Lin, M.; Wang, X. Overexpression of miR-19a inhibits colorectal cancer angiogenesis by suppressing KRAS expression Oncol. Rep. 2018, 39, 619-626. [CrossRef]

155. Jia, Z.; Wang, K.; Zhang, A.; Wang, G.; Kang, C.; Han, L.; Pu, P. miR-19a and miR-19b Overexpression in Gliomas. Pathol. Oncol. Res. 2013, 19, 847-853. [CrossRef] [PubMed]

156. Xu, J.; Tang, Y.; Bei, Y.; Ding, S.; Che, L.; Yao, J.; Wang, H.; Lv, D.; Xiao, J. miR-19b attenuates H2O2-induced apoptosis in rat H9C2 cardiomyocytes via targeting PTEN. Oncotarget 2016, 7, 10870-10878. [CrossRef] [PubMed]

157. Fan, Y.; Yin, S.; Hao, Y.; Yang, J.; Zhang, H.; Sun, C.; Ma, M.; Chang, Q.; Xi, J.J. MiR-19b promotes tumor growth and metastasis via targeting TP53. RNA 2014, 20, 765-772. [CrossRef]

158. Zaporozhchenko, I.A.; Morozkin, E.S.; Skvortsova, T.E.; Ponomaryova, A.A.; Rykova, E.Y.; Cherdyntseva, N.V.; Polovnikov, E.S.; Pashkovskaya, O.A.; Pokushalov, E.A.; Vlassov, V.V.; et al. Plasma miR-19b and miR-183 as Potential Biomarkers of Lung Cancer. PLoS ONE 2016, 11, e0165261. [CrossRef]

159. Wu, C.; Cao, Y.; He, Z.; He, J.; Hu, C.; Duan, H.; Jiang, J. Serum Levels of miR-19b and miR-146a as Prognostic Biomarkers for Non-Small Cell Lung Cancer. Tohoku J. Exp. Med. 2014, 232, 85-95. [CrossRef]

160. Copier, C.U.; León, L.; Fernández, M.; Contador, D.; Calligaris, S.D. Circulating miR-19b and miR-181b are potential biomarkers for diabetic cardiomyopathy. Sci. Rep. 2017, 7, 13514. [CrossRef]

161. Ke, T.-W.; Wei, P.-L.; Yeh, K.-T.; Chen, W.T.-L.; Cheng, Y.-W. MiR-92a Promotes Cell Metastasis of Colorectal Cancer Through PTEN-Mediated PI3K/AKT Pathway. Ann. Surg. Oncol. 2015, 22, 2649-2655. [CrossRef] [PubMed]

162. Zhang, G.J.; Li, L.F.; Yang, G.D.; Xia, S.S.; Wang, R.; Leng, Z.W.; Liu, Z.L.; Tian, H.P.; He, Y.; Meng, C.Y.; et al. MiR-92a promotes stem cell-like properties by activating Wnt/ $\beta$-catenin signaling in colorectal cancer. Oncotarget 2017, 8, 101760-101770. [CrossRef] [PubMed]

163. Wei, Q.-D.; Zheng, W.-B.; Sun, K.; Xue, Q.; Yang, C.-Z.; Li, G.-X. MiR-92a promotes the invasion and migration of colorectal cancer by targeting RECK. Int. J. Clin. Exp. Pathol. 2019, 12, 1565-1577. [PubMed]

164. Lv, H.; Zhang, Z.; Wang, Y.; Li, C.; Gong, W.; Wang, X. MicroRNA-92a promotes colorectal cancer cell growth and migration by inhibiting KLF4. Oncol. Res. 2016, 23, 283-290. [CrossRef]

165. Ma, H.; Pan, J.-S.; Jin, L.-X.; Wu, J.; Ren, Y.-D.; Chen, P.; Xiao, C.; Han, J. MicroRNA-17 92 inhibits colorectal cancer progression by targeting angiogenesis. Cancer Lett. 2016, 376, 293-302. [CrossRef]

166. Cheng, D.; Zhao, S.; Tang, H.; Zhang, D.; Sun, H.; Yu, F.; Jiang, W.; Yue, B.; Wang, J.; Zhang, M.; et al. MicroRNA-20a-5p promotes colorectal cancer invasion and metastasis by downregulating Smad4. Oncotarget 2016, 7, 45199-45213. [CrossRef]

167. Sarshar, M.; Scribano, D.; Ambrosi, C.; Palamara, A.T.; Masotti, A. Fecal microRNAs as Innovative Biomarkers of Intestinal Diseases and Effective Players in Host-Microbiome Interactions. Cancers 2020, 12, 2174. [CrossRef]

168. Zhou, T.; Zhang, G.; Liu, Z.; Xia, S.; Tian, H. Overexpression of miR-92a correlates with tumor metastasis and poor prognosis in patients with colorectal cancer. Int. J. Colorectal Dis. 2013, 28, 19-24. [CrossRef] 
169. Salvi, S.; Molinari, C.; Foca, F.; Teodorani, N.; Saragoni, L.; Puccetti, M.; Passardi, A.; Tamberi, S.; Avanzolini, A.; Lucci, E.; et al. miR-17-92a-1 cluster host gene (MIR17HG) evaluation and response to neoadjuvant chemoradiotherapy in rectal cancer. Onco. Targets. Ther. 2016, 9, 2735. [CrossRef]

170. Yu, X.; Li, Z.; Yu, J.; Chan, M.T.V.; Wu, W.K.K. MicroRNAs predict and modulate responses to chemotherapy in colorectal cancer. Cell Prolif. 2015, 48, 503-510. [CrossRef]

171. Xu, J.; Meng, Q.; Li, X.; Yang, H.; Xu, J.; Gao, N.; Sun, H.; Wu, S.; Familiari, G.; Relucenti, M.; et al. Long Noncoding RNA MIR17HG Promotes Colorectal Cancer Progression via miR-17-5p. Cancer Res. 2019, 79, 4882-4895. [CrossRef] [PubMed]

172. Kooshapur, H.; Choudhury, N.R.; Simon, B.; Mühlbauer, M.; Jussupow, A.; Fernandez, N.; Jones, A.N.; Dallmann, A.; Gabel, F.; Camilloni, C.; et al. Structural basis for terminal loop recognition and stimulation of pri-miRNA-18a processing by hnRNP A1. Nat. Commun. 2018, 9, 2479. [CrossRef] [PubMed]

173. Chaulk, S.G.; Xu, Z.; Glover, M.J.N.; Fahlman, R.P. MicroRNA miR-92a-1 biogenesis and mRNA targeting is modulated by a tertiary contact within the miR-17 92 microRNA cluster. Nucleic Acids Res. 2014, 42, 5234-5244. [CrossRef]

174. Chakraborty, S.; Mehtab, S.; Patwardhan, A.; Krishnan, Y. Pri-miR-17-92a transcript folds into a tertiary structure and autoregulates its processing. RNA 2012, 18, 1014-1028. [CrossRef] [PubMed]

175. Ounzain, S.; Micheletti, R.; Arnan, C.; Plaisance, I.; Cecchi, D.; Schroen, B.; Reverter, F.; Alexanian, M.; Gonzales, C.; Ng, S.Y.; et al CARMEN, a human super enhancer-associated long noncoding RNA controlling cardiac specification, differentiation and homeostasis. J. Mol. Cell. Cardiol. 2015, 89, 98-112. [CrossRef] [PubMed]

176. Elia, L.; Quintavalle, M.; Zhang, J.; Contu, R.; Cossu, L.; Latronico, M.V.G.; Peterson, K.L.; Indolfi, C.; Catalucci, D.; Chen, J.; et al. The knockout of miR-143 and -145 alters smooth muscle cell maintenance and vascular homeostasis in mice: Correlates with human disease. Cell Death Differ. 2009, 16, 1590-1598. [CrossRef]

177. Chen, X.; Guo, X.; Zhang, H.; Xiang, Y.; Chen, J.; Yin, Y.; Cai, X.; Wang, K.; Wang, G.; Ba, Y.; et al. Role of miR-143 targeting KRAS in colorectal tumorigenesis. Oncogene 2009, 28, 1385-1392. [CrossRef]

178. Su, J.; Liang, H.; Yao, W.; Wang, N.; Zhang, S.; Yan, X.; Feng, H.; Pang, W.; Wang, Y.; Wang, X.; et al. MiR-143 and MiR-145 regulate IGF1R to suppress cell proliferation in colorectal cancer. PLoS ONE 2014, 9, e0114420. [CrossRef]

179. Michael, M.Z.; O' Connor, S.M.; van Holst Pellekaan, N.G.; Young, G.P.; James, R.J. Reduced accumulation of specific microRNAs in colorectal neoplasia. Mol. Cancer Res. 2003, 1, 882-891.

180. Pagliuca, A.; Valvo, C.; Fabrizi, E.; di Martino, S.; Biffoni, M.; Runci, D.; Forte, S.; De Maria, R.; Ricci-Vitiani, L. Analysis of the combined action of miR-143 and miR-145 on oncogenic pathways in colorectal cancer cells reveals a coordinate program of gene repression. Oncogene 2013, 32, 4806-4813. [CrossRef]

181. Xing, A.Y.; Wang, Y.W.; Su, Z.X.; Shi, D.B.; Wang, B.; Gao, P. Catenin- $\delta 1$, negatively regulated by miR-145, promotes tumour aggressiveness in gastric cancer. J. Pathol. 2015, 236, 53-64. [CrossRef] [PubMed]

182. Ding, X.; Du, J.; Mao, K.; Wang, X.; Ding, Y.; Wang, F. MicroRNA-143-3p suppresses tumorigenesis by targeting catenin- $\delta 1$ in colorectal cancer. Onco. Targets. Ther. 2019, 12, 3255-3265. [CrossRef] [PubMed]

183. Chivukula, R.R.; Shi, G.; Acharya, A.; Mills, E.W.; Zeitels, L.R.; Anandam, J.L.; Abdelnaby, A.A.; Balch, G.C.; Mansour, J.C.; Yopp, A.C.; et al. An Essential Mesenchymal Function for miR-143/145 in Intestinal Epithelial Regeneration. Cell 2014, 157, 1104-1116. [CrossRef] [PubMed]

184. Kent, O.A.; McCall, M.N.; Cornish, T.C.; Halushka, M.K. Lessons from miR-143/145: The importance of cell-type localization of miRNAs. Nucleic Acids Res. 2014, 42, 7528-7538. [CrossRef]

185. Akao, Y.; Nakagawa, Y.; Naoe, T. MicroRNAs 143 and 145 are possible common onco-microRNAs in human cancers. Oncol. Rep. 2006, 16, 845-850. [CrossRef]

186. Yin, Y.; Yan, Z.-P.; Lu, N.-N.; Xu, Q.; He, J.; Qian, X.; Yu, J.; Guan, X.; Jiang, B.-H.; Liu, L.-Z. Downregulation of miR-145 associated with cancer progression and VEGF transcriptional activation by targeting N-RAS and IRS1. Biochim. Biophys. Acta 2013, 1829, 239-247. [CrossRef]

187. Feng, Y.; Zhu, J.; Ou, C.; Deng, Z.; Chen, M.; Huang, W.; Li, L. MicroRNA-145 inhibits tumour growth and metastasis in colorectal cancer by targeting fascin-1. Br. J. Cancer 2014, 110, 2300-2309. [CrossRef]

188. Huang, F.T.; Chen, W.Y.; Gu, Z.Q.; Zhuang, Y.Y.; Li, C.Q.; Wang, L.Y.; Peng, J.F.; Zhu, Z.; Luo, X.; Li, Y.H.; et al. The novel long intergenic noncoding RNA UCC promotes colorectal cancer progression by sponging MIR-143. Cell Death Dis. 2017, 8, e2778 [CrossRef]

189. Luan, Y.; Li, X.; Luan, Y.; Zhao, R.; Li, Y.; Liu, L.; Hao, Y.; Oleg Vladimir, B.; Jia, L. Circulating lncRNA UCA1 Promotes Malignancy of Colorectal Cancer via the miR-143/MYO6 Axis. Mol. Ther. Nucleic Acids 2020, 19, 790-803. [CrossRef]

190. Hu, Y.; Ma, Z.; He, Y.; Liu, W.; Su, Y.; Tang, Z. PART-1 functions as a competitive endogenous RNA for promoting tumor progression by sponging miR-143 in colorectal cancer. Biochem. Biophys. Res. Commun. 2017, 490, 317-323. [CrossRef]

191. Xie, H.; Ren, X.; Xin, S.; Lan, X.; Lu, G.; Lin, Y.; Yang, S.; Zeng, Z.; Liao, W.; Ding, Y.-Q.; et al. Emerging roles of circRNA_001569 targeting miR-145 in the proliferation and invasion of colorectal cancer. Oncotarget 2016, 7, 26680-26691. [CrossRef] [PubMed]

192. Slaby, O.; Svoboda, M.; Fabian, P.; Smerdova, T.; Knoflickova, D.; Bednarikova, M.; Nenutil, R.; Vyzula, R. Altered Expression of miR-21, miR-31, miR-143 and miR-145 Is Related to Clinicopathologic Features of Colorectal Cancer. Oncology 2007, 72, 397-402. [CrossRef] [PubMed]

193. Akao, Y.; Nakagawa, Y.; Hirata, I.; Iio, A.; Itoh, T.; Kojima, K.; Nakashima, R.; Kitade, Y.; Naoe, T. Role of anti-oncomirs miR-143 and -145 in human colorectal tumors. Cancer Gene Ther. 2010, 17, 398-408. [CrossRef] [PubMed] 
194. Ahmed, F.E.; Ahmed, N.C.; Vos, P.W.; Bonnerup, C.; Atkins, J.N.; Casey, M.; Nuovo, G.J.; Naziri, W.; Wiley, J.E.; Mota, H.; et al. Diagnostic microRNA markers to screen for sporadic human colon cancer in stool: I. Proof of principle. Cancer Genomics Proteomics 2013, 10, 93-113. [PubMed]

195. Li, J.M.; Zhao, R.H.; Li, S.T.; Xie, C.X.; Jiang, H.H.; Ding, W.J.; Du, P.; Chen, W.; Yang, M.; Cui, L. Down-regulation of fecal miR-143 and miR-145 as potential markers for colorectal cancer. Saudi Med. J. 2012, 33, 24-29. [PubMed]

196. Arndt, G.M.; Dossey, L.; Cullen, L.M.; Lai, A.; Druker, R.; Eisbacher, M.; Zhang, C.; Tran, N.; Fan, H.; Retzlaff, K.; et al. Characterization of global microRNA expression reveals oncogenic potential of miR-145 in metastatic colorectal cancer. BMC Cancer 2009, 9, 374. [CrossRef] [PubMed]

197. Humphries, B.; Yang, C. The microRNA-200 family: Small molecules with novel roles in cancer development, progression and therapy. Oncotarget 2015, 6, 6472-6498. [CrossRef] [PubMed]

198. Korpal, M.; Lee, E.S.; Hu, G.; Kang, Y. The miR-200 Family Inhibits Epithelial-Mesenchymal Transition and Cancer Cell Migration by Direct Targeting of E-cadherin Transcriptional Repressors ZEB1 and ZEB2. J. Biol. Chem. 2008, 283, 14910-14914. [CrossRef]

199. Gregory, P.A.; Bert, A.G.; Paterson, E.L.; Barry, S.C.; Tsykin, A.; Farshid, G.; Vadas, M.A.; Khew-Goodall, Y.; Goodall, G.J. The miR-200 family and miR-205 regulate epithelial to mesenchymal transition by targeting ZEB1 and SIP1. Nat. Cell Biol. 2008, 10, 593-601. [CrossRef]

200. Browne, G.; Sayan, A.E.; Tulchinsky, E. ZEB proteins link cell motility with cell cycle control and cell survival in cancer. Cell Cycle 2010, 9, 886-891. [CrossRef]

201. Drápela, S.; Bouchal, J.; Jolly, M.K.; Culig, Z.; Souček, K. ZEB1: A Critical Regulator of Cell Plasticity, DNA Damage Response, and Therapy Resistance. Front. Mol. Biosci. 2020, 7, 1-10. [CrossRef] [PubMed]

202. Bracken, C.P.; Gregory, P.A.; Kolesnikoff, N.; Bert, A.G.; Wang, J.; Shannon, M.F.; Goodall, G.J. A double-negative feedback loop between ZEB1-SIP1 and the microRNA-200 family regulates epithelial-mesenchymal transition. Cancer Res. 2008, 68, 7846-7854. [CrossRef] [PubMed]

203. O'Brien, S.J.; Carter, J.V.; Burton, J.F.; Oxford, B.G.; Schmidt, M.N.; Hallion, J.C.; Galandiuk, S. The role of the miR-200 family in epithelial-mesenchymal transition in colorectal cancer: A systematic review. Int. J. Cancer 2018, 142, 2501-2511. [CrossRef] [PubMed]

204. Hur, K.; Toiyama, Y.; Takahashi, M.; Balaguer, F.; Nagasaka, T.; Koike, J.; Hemmi, H.; Koi, M.; Boland, C.R.; Goel, A. MicroRNA200c modulates epithelial-tomesenchymal transition (EMT) in human colorectal cancer metastasis. Gut 2013, 62, 1315-1326. [CrossRef]

205. Carter, J.V.; O’Brien, S.J.; Burton, J.F.; Oxford, B.G.; Stephen, V.; Hallion, J.; Bishop, C.; Galbraith, N.J.; Eichenberger, M.R.; Sarojini, H.; et al. The microRNA-200 family acts as an oncogene in colorectal cancer by inhibiting the tumor suppressor RASSF2. Oncol. Lett. 2019, 18, 3994-4007. [CrossRef]

206. Pecot, C.V.; Rupaimoole, R.; Yang, D.; Akbani, R.; Ivan, C.; Lu, C.; Wu, S.; Han, H.D.; Shah, M.Y.; Rodriguez-Aguayo, C.; et al Tumour angiogenesis regulation by the miR-200 family. Nat. Commun. 2013, 4, 1-14. [CrossRef]

207. Schliekelman, M.J.; Gibbons, D.L.; Faca, V.M.; Creighton, C.J.; Rizvi, Z.H.; Zhang, Q.; Wong, C.H.; Wang, H.; Ungewiss, C.; Ahn, Y.H.; et al. Targets of the tumor suppressor miR-200 in regulation of the epithelial-mesenchymal transition in cancer. Cancer Res. 2011, 71, 7670-7682. [CrossRef]

208. Yu, C.; Wan, H.; Shan, R.; Wen, W.; Li, J.; Luo, D.; Wan, R. The prognostic value of the MiR-200 family in colorectal cancer: A meta-analysis with 1882 patients. J. Cancer 2019, 10, 4009-4016. [CrossRef]

209. Sun, Y.; Shen, S.; Liu, X.; Tang, H.; Wang, Z.; Yu, Z.; Li, X.; Wu, M. MiR-429 inhibits cells growth and invasion and regulates EMT-related marker genes by targeting Onecut2 in colorectal carcinoma. Mol. Cell. Biochem. 2014, 390, 19-30. [CrossRef]

210. Ding, L.; Yu, L.L.; Han, N.; Zhang, B.T. miR-141 promotes colon cancer cell proliferation by inhibiting MAP2K4. Oncol. Lett. 2017, 13, 1665-1671. [CrossRef]

211. Hu, M.; Xia, M.; Chen, X.; Lin, Z.; Xu, Y.; Ma, Y.; Su, L. MicroRNA-141 regulates smad interacting protein 1 (SIP1) and inhibits migration and invasion of colorectal cancer cells. Dig. Dis. Sci. 2010, 55, 2365-2372. [CrossRef] [PubMed]

212. Wu, P.P.; Zhu, H.Y.; Sun, X.F.; Chen, L.X.; Zhou, Q.; Chen, J. MicroRNA-141 regulates the tumour suppressor DLC1 in colorectal cancer. Neoplasma 2013, 62, 705-712. [CrossRef] [PubMed]

213. Yu, L.; Cao, C.; Li, X.; Zhang, M.; Gu, Q.; Gao, H.; Balic, J.J.; Xu, D.; Zhang, L.; Ying, L.; et al. Complete loss of miR-200 family induces EMT associated cellular senescence in gastric cancer. Oncogene 2021, 41, 26-36. [CrossRef] [PubMed]

214. Maierthaler, M.; Benner, A.; Hoffmeister, M.; Surowy, H.; Jansen, L.; Knebel, P.; Chang-Claude, J.; Brenner, H.; Burwinkel, B. Plasma miR-122 and miR-200 family are prognostic markers in colorectal cancer. Int. J. Cancer 2017, 140, 176-187. [CrossRef] [PubMed]

215. Pichler, M.; Ress, A.L.; Winter, E.; Stiegelbauer, V.; Karbiener, M.; Schwarzenbacher, D.; Scheideler, M.; Ivan, C.; Jahn, S.W.; Kiesslich, T.; et al. MiR-200a regulates epithelial to mesenchymal transition-related gene expression and determines prognosis in colorectal cancer patients. Br. J. Cancer 2014, 110, 1614-1621. [CrossRef]

216. Cheng, H.; Zhang, L.; Cogdell, D.E.; Zheng, H.; Schetter, A.J.; Nykter, M.; Harris, C.C.; Chen, K.; Hamilton, S.R.; Zhang, W. Circulating plasma MiR-141 is a novel biomarker for metastatic colon cancer and predicts poor prognosis. PLoS ONE 2011, 6, e17745. [CrossRef] 
217. Liang, W.C.; Fu, W.M.; Wong, C.W.; Wang, Y.; Wang, W.M.; Hu, G.X.; Zhang, L.; Xiao, L.J.; Wan, D.C.C.; Zhang, J.F.; et al. The LncRNA H19 promotes epithelial to mesenchymal transition by functioning as MiRNA sponges in colorectal cancer. Oncotarget 2015, 6, 22513-22525. [CrossRef]

218. O'Brien, S.J.; Fiechter, C.; Burton, J.; Hallion, J.; Paas, M.; Patel, A.; Patel, A.; Rochet, A.; Scheurlen, K.; Gardner, S.; et al. Long non-coding RNA ZFAS1 is a major regulator of epithelial-mesenchymal transition through miR-200/ZEB1/E-cadherin, vimentin signaling in colon adenocarcinoma. Cell Death Discov. 2021, 7, 1-14. [CrossRef]

219. Wu, G.; Xue, M.; Zhao, Y.; Han, Y.; Li, C.; Zhang, S.; Zhang, J.; Xu, J. Long noncoding rna zeb1-as1 acts as a sponge of mir-141-3p to inhibit cell proliferation in colorectal cancer. Int. J. Med. Sci. 2020, 17, 1589-1597. [CrossRef]

220. Cheng, Z.; Li, Z.; Ma, K.; Li, X.; Tian, N.; Duan, J.; Xiao, X.; Wang, Y. Long non-coding RNA XIST promotes glioma tumorigenicity and angiogenesis by acting as a molecular sponge of miR-429. J. Cancer 2017, 8, 4106-4116. [CrossRef]

221. Schetter, A.J.; Leung, S.Y.; Sohn, J.J.; Zanetti, K.A.; Bowman, E.D.; Yanaihara, N.; Yuen, S.T.; Chan, T.L.; Kwong, D.L.W.; Au, G.K.H.; et al. MicroRNA Expression Profiles Associated With Prognosis and Therapeutic Outcome in Colon Adenocarcinoma. J. Am. Med. Assoc. 2008, 299, 425-436. [CrossRef] [PubMed]

222. Fu, Q.; Zhang, J.; Xu, X.; Qian, F.; Feng, K.; Ma, J. miR-203 is a predictive biomarker for colorectal cancer and its expression is associated with BIRC5. Tumor Biol. 2016, 37, 15989-15995. [CrossRef] [PubMed]

223. Chiang, Y.; Song, Y.; Wang, Z.; Chen, Y.; Yue, Z.; Xu, H.; Xing, C.; Liu, Z. Aberrant Expression of miR-203 and Its Clinical Significance in Gastric and Colorectal Cancers. J. Gastrointest. Surg. 2011, 15, 63-70. [CrossRef] [PubMed]

224. Yi, R.; Poy, M.N.; Stoffel, M.; Fuchs, E. A skin microRNA promotes differentiation by repressing "stemness". Nature 2008, 452, 225-229. [CrossRef]

225. DeCastro, A.J.; Dunphy, K.A.; Hutchinson, J.; Balboni, A.L.; Cherukuri, P.; Jerry, D.J.; DiRenzo, J. MiR203 mediates subversion of stem cell properties during mammary epithelial differentiation via repression of $\delta \mathrm{nP} 63 \alpha$ and promotes mesenchymal-to-epithelial transition. Cell Death Dis. 2013, 4, 1-10. [CrossRef]

226. Patturajan, M.; Nomoto, S.; Sommer, M.; Fomenkov, A.; Hibi, K.; Zangen, R.; Poliak, N.; Califano, J.; Trink, B.; Ratovitski, E.; et al $\Delta$ Np63 induces $\beta$-catenin nuclear accumulation and signaling. Cancer Cell 2002, 1, 369-379. [CrossRef]

227. Riemondy, K.; Wang, X.; Torchia, E.C.; Roop, D.R.; Yi, R. MicroRNA-203 represses selection and expansion of oncogenic Hras transformed tumor initiating cells. Elife 2015, 4, e07004. [CrossRef]

228. Lai, H.T.; Tseng, W.K.; Huang, S.W.; Chao, T.C.; Su, Y. MicroRNA-203 diminishes the stemness of human colon cancer cells by suppressing GATA6 expression. J. Cell. Physiol. 2020, 235, 2866-2880. [CrossRef]

229. Ju, S.Y.; Chiou, S.H.; Su, Y. Maintenance of the stemness in CD44+ HCT-15 and HCT-116 human colon cancer cells requires miR-203 suppression. Stem Cell Res. 2014, 12, 86-100. [CrossRef]

230. Li, P.; Zhou, H.; Zhu, X.; Ma, G.; Liu, C.; Lin, B.; Mao, W. High expression of NEDD9 predicts adverse outcomes of colorectal cancer patients. Int. J. Clin. Exp. Pathol. 2014, 7, 2565-2570.

231. Han, R.; Sun, Q.; Wu, J.; Zheng, P.; Zhao, G. Sodium Butyrate Upregulates miR-203 Expression to Exert Anti-Proliferation Effect on Colorectal Cancer Cells. Cell. Physiol. Biochem. 2016, 39, 1919-1929. [CrossRef]

232. Li, J.; Chen, Y.; Zhao, J.; Kong, F.; Zhang, Y. MiR-203 reverses chemoresistance in p53-mutated colon cancer cells through downregulation of Akt2 expression. Cancer Lett. 2011, 304, 52-59. [CrossRef] [PubMed]

233. Liu, Y.; Gao, S.; Chen, X.; Liu, M.; Mao, C.; Fang, X. Overexpression of miR-203 sensitizes paclitaxel (Taxol)-resistant colorectal cancer cells through targeting the salt-inducible kinase 2 (SIK2). Tumor Biol. 2016, 37, 12231-12239. [CrossRef] [PubMed]

234. Zhong, X.; Xiao, Y.; Chen, C.; Wei, X.; Hu, C.; Ling, X.; Liu, X. MicroRNA-203-mediated posttranscriptional deregulation of CPEB4 contributes to colorectal cancer progression. Biochem. Biophys. Res. Commun. 2015, 466, 206-213. [CrossRef]

235. Li, T.; Gao, F.; Zhang, X.P. MiR-203 enhances chemosensitivity to 5-fluorouracil by targeting thymidylate synthase in colorectal cancer. Oncol. Rep. 2015, 33, 607-614. [CrossRef]

236. Shen, B.; Yuan, Y.; Zhang, Y.; Yu, S.; Peng, W.; Huang, X.; Feng, J. Long non-coding RNA FBXL19-AS1 plays oncogenic role in colorectal cancer by sponging miR-203. Biochem. Biophys. Res. Commun. 2017, 488, 67-73. [CrossRef] [PubMed]

237. Ma, S.; Yang, D.; Liu, Y.; Wang, Y.; Lin, T.; Li, Y.; Yang, S.; Zhang, W.; Zhang, R. LncRNA BANCR promotes tumorigenesis and enhances adriamycin resistance in colorectal cancer. Aging 2018, 10, 2062-2078. [CrossRef]

238. Zhao, L.; Liu, C.; Yan, S.; Hu, G.; Xiang, K.; Xiang, H.; Yu, H. LINC00657 promotes colorectal cancer stem-like cell invasion by functioning as a miR-203a sponge. Biochem. Biophys. Res. Commun. 2020, 529, 500-506. [CrossRef]

239. Ye, H.; Hao, H.; Wang, J.; Chen, R.; Huang, Z. miR-203 as a novel biomarker for the diagnosis and prognosis of colorectal cancer: A systematic review and meta-analysis. Onco. Targets. Ther. 2017, 10, 3685-3696. [CrossRef]

240. Valeri, N.; Braconi, C.; Gasparini, P.; Murgia, C.; Lampis, A.; Paulus-Hock, V.; Hart, J.R.; Ueno, L.; Grivennikov, S.I.; Lovat, F.; et al. MicroRNA-135b promotes cancer progression by acting as a downstream effector of oncogenic pathways in colon cancer. Cancer Cell 2014, 25, 469-483. [CrossRef]

241. Nagel, R.; Le Sage, C.; Diosdado, B.; Van Der Waal, M.; Oude Vrielink, J.A.F.; Bolijn, A.; Meijer, G.A.; Agami, R. Regulation of the adenomatous polyposis coli gene by the miR-135 family in colorectal cancer. Cancer Res. 2008, 68, 5795-5802. [CrossRef] [PubMed]

242. Yang, X.; Wang, X.; Nie, F.; Liu, T.; Yu, X.; Wang, H.; Li, Q.; Peng, R.; Mao, Z.; Zhou, Q.; et al. MiR-135 family members mediate podocyte injury through the activation of Wnt/ $\beta$-catenin signaling. Int. J. Mol. Med. 2015, 36, 669-677. [CrossRef] [PubMed] 
243. Yang, Y.; Ishak Gabra, M.B.; Hanse, E.A.; Lowman, X.H.; Tran, T.Q.; Li, H.; Milman, N.; Liu, J.; Reid, M.A.; Locasale, J.W.; et al. MiR135 suppresses glycolysis and promotes pancreatic cancer cell adaptation to metabolic stress by targeting phosphofructokinase-1. Nat. Commun. 2019, 10,1-15. [CrossRef]

244. Zhou, W.; Li, X.; Liu, F.; Xiao, Z.; He, M.; Shen, S.; Liu, S. MiR-135a promotes growth and invasion of colorectal cancer via metastasis suppressor 1 in vitro. Acta Biochim. Biophys. Sin. 2012, 44, 838-846. [CrossRef] [PubMed]

245. Li, J.; Liang, H.; Bai, M.; Ning, T.; Wang, C.; Fan, Q.; Wang, Y.; Fu, Z.; Wang, N.; Liu, R.; et al. miR-135b promotes cancer progression by targeting transforming growth factor beta receptor II (TGFBR2) in colorectal cancer. PLoS ONE 2015, 10, e130194. [CrossRef]

246. Parsons, R.; Myeroff, L.L.; Liu, B.; Willson, J.K.; Markowitz, S.D.; Kinzler, K.W.; Vogelstein, B. Microsatellite instability and mutations of the transforming growth factor beta type II receptor gene in colorectal cancer. Cancer Res. 1995, 55, 5548-5550. [PubMed]

247. Zhang, Y.; Zhang, Z.; Yi, Y.; Wang, Y.; Fu, J. CircNOL10 acts as a sponge of miR-135a/b-5p in suppressing colorectal cancer progression via regulating KLF9. Onco. Targets. Ther. 2020, 13, 5165-5176. [CrossRef]

248. Xu, X.M.; Qian, J.C.; Deng, Z.L.; Cai, Z.; Tang, T.; Wang, P.; Zhang, K.H.; Cai, J.P. Expression of miR-21, miR-31, miR-96 and miR-135b is correlated with the clinical parameters of colorectal cancer. Oncol. Lett. 2012, 4, 339-345. [CrossRef]

249. Vickers, M.M.; Bar, J.; Gorn-Hondermann, I.; Yarom, N.; Daneshmand, M.; Hanson, J.E.L.; Addison, C.L.; Asmis, T.R.; Jonker, D.J.; Maroun, J.; et al. Stage-dependent differential expression of microRNAs in colorectal cancer: Potential role as markers of metastatic disease. Clin. Exp. Metastasis 2012, 29, 123-132. [CrossRef]

250. Jia, L.; Luo, S.; Ren, X.; Li, Y.; Hu, J.; Liu, B.; Zhao, L.; Shan, Y.; Zhou, H. miR-182 and miR-135b Mediate the Tumorigenesis and Invasiveness of Colorectal Cancer Cells via Targeting ST6GALNAC2 and PI3K/AKT Pathway. Dig. Dis. Sci. 2017, 62, 3447-3459. [CrossRef]

251. Mencía, A.; Modamio-Høybjør, S.; Redshaw, N.; Morín, M.; Mayo-Merino, F.; Olavarrieta, L.; Aguirre, L.A.; Del Castillo, I.; Steel, K.P.; Dalmay, T.; et al. Mutations in the seed region of human miR-96 are responsible for nonsyndromic progressive hearing loss. Nat. Genet. 2009, 41, 609-613. [CrossRef]

252. Pierce, M.L.; Weston, M.D.; Fritzsch, B.; Gabel, H.W.; Ruvkun, G.; Soukup, G.A. MicroRNA-183 family conservation and ciliated neurosensory organ expression. Evol. Dev. 2008, 10, 106-113. [CrossRef]

253. Guttilla, I.K.; White, B.A. Coordinate regulation of FOXO1 by miR-27a, miR-96, and miR-182 in breast cancer cells. J. Biol. Chem. 2009, 284, 23204-23216. [CrossRef]

254. Gao, F.; Wang, W. MicroRNA-96 promotes the proliferation of colorectal cancer cells and targets tumor protein p53 inducible nuclear protein 1, forkhead box protein O1 (FOXO1) and FOXO3a. Mol. Med. Rep. 2015, 11, 1200-1206. [CrossRef]

255. Suzuki, R.; Amatya, V.J.; Kushitani, K.; Kai, Y.; Kambara, T.; Takeshima, Y. miR-182 and miR-183 promote cell proliferation and invasion by targeting FOXO1 in mesothelioma. Front. Oncol. 2018, 8, 1-9. [CrossRef]

256. Huangfu, L.; Liang, H.; Wang, G.; Su, X.; Li, L.; Du, Z.; Hu, M.; Dong, Y.; Bai, X.; Liu, T.; et al. miR-183 regulates autophagy and apoptosis in colorectal cancer through targeting of UVRAG. Oncotarget 2016, 7, 4735-4745. [CrossRef]

257. Xiang, L.; Chen, X.J.; Wu, K.C.; Zhang, C.J.; Zhou, G.H.; Lv, J.N.; Sun, L.F.; Cheng, F.F.; Cai, X.B.; Jin, Z.B. MiR-183/96 plays a pivotal regulatory role in mouse photoreceptor maturation and maintenance. Proc. Natl. Acad. Sci. USA 2017, 114, 6376-6381. [CrossRef]

258. He, P.Y.; Yip, W.K.; Jabar, M.F.; Mohtarrudin, N.; Dusa, N.M.; Seow, H.F. Effect of the miR-96-5p inhibitor and mimic on the migration and invasion of the SW480-7 colorectal cancer cell line. Oncol. Lett. 2019, 18, 1949-1960. [CrossRef]

259. Li, P.; Sheng, C.; Huang, L.; Zhang, H.; Huang, L.; Cheng, Z.; Zhu, Q. MiR-183/-96/-182 cluster is up-regulated in most breast cancers and increases cell proliferation and migration. Breast Cancer Res. 2014, 16, 1-17. [CrossRef]

260. Iseki, Y.; Shibutani, M.; Maeda, K.; Nagahara, H.; Fukuoka, T.; Matsutani, S.; Hirakawa, K.; Ohira, M. MicroRNA-96 promotes tumor invasion in colorectal cancer via RECK. Anticancer Res. 2018, 38, 2031-2035. [CrossRef]

261. Bi, D.P.; Yin, C.H.; Zhang, X.Y.; Yang, N.N.; Xu, J.Y. MIR-183 functions as an oncogene by targeting ABCA1 in colon cancer. Oncol. Rep. 2016, 35, 2873-2879. [CrossRef]

262. Ge, T.; Xiang, P.; Mao, H.; Tang, S.; Zhou, J.; Zhang, Y. Inhibition of miR-96 enhances the sensitivity of colorectal cancer cells to oxaliplatin by targeting TPM1. Exp. Ther. Med. 2020, 20, 2134-2140. [CrossRef]

263. Zheng, S.; Zhong, Y.F.; Tan, D.M.; Xu, Y.; Chen, H.X.; Wang, D. miR-183-5p enhances the radioresistance of colorectal cancer by directly targeting ATG5. J. Biosci. 2019, 44, 1-11. [CrossRef]

264. Rapti, S.M.; Kontos, C.K.; Papadopoulos, I.N.; Scorilas, A. High miR-96 levels in colorectal adenocarcinoma predict poor prognosis, particularly in patients without distant metastasis at the time of initial diagnosis. Tumor Biol. 2016, 37, 11815-11824. [CrossRef]

265. Yue, C.; Chen, J.; Li, Z.; Li, L.; Chen, J.; Guo, Y. microRNA-96 promotes occurrence and progression of colorectal cancer via regulation of the AMPK $\alpha 2-\mathrm{FTO}-\mathrm{m} 6 \mathrm{~A} / \mathrm{MYC}$ axis. J. Exp. Clin. Cancer Res. 2020, 39, 1-15. [CrossRef]

266. Zhang, Q.; Ren, W.; Huang, B.; Yi, L.; Zhu, H. MicroRNA-183/182/96 cooperatively regulates the proliferation of colon cancer cells. Mol. Med. Rep. 2015, 12, 668-674. [CrossRef]

267. Zhou, T.; Zhang, G.J.; Zhou, H.; Xiao, H.X.; Li, Y. Overexpression of microRNA-183 in human colorectal cancer and its clinical significance. Eur. J. Gastroenterol. Hepatol. 2014, 26, 229-233. [CrossRef] 
268. Ress, A.L.; Stiegelbauer, V.; Winter, E.; Schwarzenbacher, D.; Kiesslich, T.; Lax, S.; Jahn, S.; Deutsch, A.; Bauernhofer, T.; Ling, H.; et al. MiR-96-5p influences cellular growth and is associated with poor survival in colorectal cancer patients. Mol. Carcinog. 2015, 54, 1442-1450. [CrossRef]

269. Ning, S.; Liu, H.; Gao, B.; Wei, W.; Yang, A.; Li, J.; Zhang, L. MiR-155, miR-96 and miR-99a as potential diagnostic and prognostic tools for the clinical management of hepatocellular carcinoma. Oncol. Lett. 2019, 18, 3381-3387. [CrossRef]

270. Wu, H.; Zhou, J.; Mei, S.; Wu, D.; Mu, Z.; Chen, B.; Xie, Y.; Ye, Y.; Liu, J. Circulating exosomal microRNA-96 promotes cell proliferation, migration and drug resistance by targeting LMO7. J. Cell. Mol. Med. 2017, 21, 1228-1236. [CrossRef]

271. Shao, S.; Wang, C.; Wang, S.; Zhang, H.; Zhang, Y. LncRNA STXBP5-AS1 suppressed cervical cancer progression via targeting miR-96-5p/PTEN axis. Biomed. Pharmacother. 2019, 117, 109082. [CrossRef] [PubMed]

272. Zhang, Y.; Yang, H.; Du, Y.; Liu, P.; Zhang, J.; Li, Y.; Shen, H.; Xing, L.; Xue, X.; Chen, J.; et al. Long noncoding RNA TP53TG1 promotes pancreatic ductal adenocarcinoma development by acting as a molecular sponge of microRNA-96. Cancer Sci. 2019, 110, 2760-2772. [CrossRef] [PubMed]

273. Shen, T.; Cheng, X.; Liu, X.; Xia, C.; Zhang, H.; Pan, D.; Zhang, X.; Li, Y. Circ_0026344 restrains metastasis of human colorectal cancer cells via miR-183. Artif. Cells Nanomed. Biotechnol. 2019, 47, 4038-4045. [CrossRef] [PubMed]

274. Monticelli, S.; Ansel, K.M.; Xiao, C.; Socci, N.D.; Krichevsky, A.M.; Thai, T.H.; Rajewsky, N.; Marks, D.S.; Sander, C.; Rajewsky, K.; et al. MicroRNA profiling of the murine hematopoietic system. Genome Biol. 2005, 6, 1-15. [CrossRef]

275. Xiao, C.; Calado, D.P.; Galler, G.; Thai, T.H.; Patterson, H.C.; Wang, J.; Rajewsky, N.; Bender, T.P.; Rajewsky, K. MiR-150 Controls B Cell Differentiation by Targeting the Transcription Factor c-Myb. Cell 2007, 131, 146-159. [CrossRef]

276. Feng, J.; Yang, Y.; Zhang, P.; Wang, F.; Ma, Y.; Qin, H.; Wang, Y. miR-150 functions as a tumour suppressor in human colorectal cancer by targeting c-Myb. J. Cell. Mol. Med. 2014, 18, 2125-2134. [CrossRef]

277. Ying, W.; Tseng, A.; Chang, R.C.A.; Wang, H.; Lin, Y.L.; Kanameni, S.; Brehm, T.; Morin, A.; Jones, B.; Splawn, T.; et al. MiR-150 regulates obesity-Associated insulin resistance by controlling B cell functions. Sci. Rep. 2016, 6, 1-12. [CrossRef]

278. He, Z.; Dang, J.; Song, A.; Cui, X.; Ma, Z.; Zhang, Y. The involvement of miR-150/ $\beta$-catenin axis in colorectal cancer progression. Biomed. Pharmacother. 2020, 121, 109495. [CrossRef]

279. Chen, X.; Xu, X.; Pan, B.; Zeng, K.; Xu, M.; Liu, X.; He, B.; Pan, Y.; Sun, H.; Wang, S. miR-150-5p suppresses tumor progression by targeting VEGFA in colorectal cancer. Aging 2018, 10, 3421-3437. [CrossRef]

280. Wang, W.H.; Chen, J.; Zhao, F.; Zhang, B.R.; Yu, H.S.; Jin, H.Y.; Dai, J.H. MiR-150-5p suppresses colorectal cancer cell migration and invasion through targeting MUC4. Asian Pacific J. Cancer Prev. 2014, 15, 6269-6273. [CrossRef]

281. Zhou, L.; Qi, X.; Potashkin, J.A.; Abdul-Karim, F.W.; Gorodeski, G.I. MicroRNAs miR-186 and miR-150 down-regulate expression of the pro-apoptotic purinergic P2X7 receptor by activation of instability sites at the $3^{\prime}$-untranslated region of the gene that decrease steady-state levels of the transcript. J. Biol. Chem. 2008, 283, 28274-28286. [CrossRef] [PubMed]

282. Wu, Q.; Jin, H.; Yang, Z.; Luo, G.; Lu, Y.; Li, K.; Ren, G.; Su, T.; Pan, Y.; Feng, B.; et al. MiR-150 promotes gastric cancer proliferation by negatively regulating the pro-apoptotic gene EGR2. Biochem. Biophys. Res. Commun. 2010, 392, 340-345. [CrossRef] [PubMed]

283. Liu, F.; Di Wang, X. miR-150-5p represses TP53 tumor suppressor gene to promote proliferation of colon adenocarcinoma. Sci. Rep. 2019, 9, 1-7. [CrossRef] [PubMed]

284. Slattery, M.L.; Herrick, J.S.; Mullany, L.E.; Samowitz, W.S.; Sevens, J.R.; Sakoda, L.; Wolff, R.K. The co-regulatory networks of tumor suppressor genes, oncogenes, and miRNAs in colorectal cancer. Genes Chromosom. Cancer 2017, 56, 769-787. [CrossRef] [PubMed]

285. Yanlei, M.; Zhang, P.; Wang, F.; Zhang, H.; Yang, J.; Peng, J.; Liu, W.; Qin, H. miR-150 as a potential biomarker associated with prognosis and therapeutic outcome in colorectal cancer. Gut 2012, 61, 1447-1453. [CrossRef]

286. Chen, X.; Zeng, K.; Xu, M.; Hu, X.; Liu, X.; Xu, T.; He, B.; Pan, Y.; Sun, H.; Wang, S. SP1-induced lncRNA-ZFAS1 contributes to colorectal cancer progression via the miR-150-5p/VEGFA axis. Cell Death Dis. 2018, 9, 1-18. [CrossRef]

287. Zhou, T.; Wu, L.; Ma, N.; Tang, F.; Zong, Z.; Chen, S. LncRNA PART1 regulates colorectal cancer via targeting miR-150-5p/miR520h/CTNNB1 and activating Wnt/ $\beta$-catenin pathway. Int. J. Biochem. Cell Biol. 2020, 118, 105637. [CrossRef]

288. Van Rooij, E.; Sutherland, L.B.; Liu, N.; Williams, A.H.; McAnally, J.; Gerard, R.D.; Richardson, J.A.; Olson, E.N. A signature pattern of stress-responsive microRNAs that can evoke cardiac hypertrophy and heart failure. Proc. Natl. Acad. Sci. USA 2006, 103, 18255-18260. [CrossRef]

289. Porrello, E.R.; Johnson, B.A.; Aurora, A.B.; Simpson, E.; Nam, Y.J.; Matkovich, S.J.; Dorn, G.W.; Van Rooij, E.; Olson, E.N. MiR-15 family regulates postnatal mitotic arrest of cardiomyocytes. Circ. Res. 2011, 109, 670-679. [CrossRef]

290. Murakami, Y.; Yasuda, T.; Saigo, K.; Urashima, T.; Toyoda, H.; Okanoue, T.; Shimotohno, K. Comprehensive analysis of microRNA expression patterns in hepatocellular carcinoma and non-tumorous tissues. Oncogene 2006, 25, 2537-2545. [CrossRef]

291. Xu, T.; Zhu, Y.; Xiong, Y.; Ge, Y.Y.; Yun, J.P.; Zhuang, S.M. MicroRNA-195 suppresses tumorigenicity and regulates G1/S transition of human hepatocellular carcinoma cells. Hepatology 2009, 50, 113-121. [CrossRef] [PubMed]

292. Chen, C.Y.; Chao, Y.M.; Lin, H.F.; Chen, C.J.; Chen, C.S.; Yang, J.L.; Chan, J.Y.H.; Juo, S.H.H. miR-195 reduces age-related blood-brain barrier leakage caused by thrombospondin-1-mediated selective autophagy. Aging Cell 2020, 19, 1-17. [CrossRef] [PubMed]

293. Li, B.; Wang, S.; Wang, S. MiR-195 suppresses colon cancer proliferation and metastasis by targeting WNT3A. Mol. Genet. Genom. 2018, 293, 1245-1253. [CrossRef] [PubMed] 
294. Kang, D.W.; Min, D.S. Positive feedback regulation between phospholipase D and Wnt signaling promotes Wnt-Driven anchorageindependent growth of colorectal cancer cells. PLoS ONE 2010, 5, e12109. [CrossRef]

295. Lin, X.; Wang, S.; Sun, M.; Zhang, C.; Wei, C.; Yang, C.; Dou, R.; Liu, Q.; Xiong, B. MiR-195-5p/NOTCH2-mediated EMT modulates IL-4 secretion in colorectal cancer to affect M2-like TAM polarization. J. Hematol. Oncol. 2019, 12, 1-14. [CrossRef]

296. Liu, L.; Chen, L.; Xu, Y.; Li, R.; Du, X. MicroRNA-195 promotes apoptosis and suppresses tumorigenicity of human colorectal cancer cells. Biochem. Biophys. Res. Commun. 2010, 400, 236-240. [CrossRef]

297. Wang, X.; Wang, J.; Ma, H.; Zhang, J.; Zhou, X. Downregulation of miR-195 correlates with lymph node metastasis and poor prognosis in colorectal cancer. Med. Oncol. 2012, 29, 919-927. [CrossRef]

298. Jin, Y.; Wang, M.; Hu, H.; Huang, Q.; Chen, Y.; Wang, G. Overcoming stemness and chemoresistance in colorectal cancer through miR-195-5p-modulated inhibition of notch signaling. Int. J. Biol. Macromol. 2018, 117, 445-453. [CrossRef]

299. Zhang, X.; Xu, J.; Jiang, T.; Liu, G.; Wang, D.; Lu, Y. MicroRNA-195 suppresses colorectal cancer cells proliferation via targeting FGF2 and regulating Wnt/ $\beta$-catenin pathway. Am. J. Cancer Res. 2016, 6, 2631-2640.

300. Wang, L.; Qian, L.; Li, X.; Yan, J. MicroRNA-195 inhibits colorectal cancer cell proliferation, colony-formation and invasion through targeting CARMA3. Mol. Med. Rep. 2014, 10, 473-478. [CrossRef]

301. Luo, Q.; Zhang, Z.; Dai, Z.; Basnet, S.; Li, S.; Xu, B.; Ge, H. Tumor-suppressive microRNA-195-5p regulates cell growth and inhibits cell cycle by targeting cyclin dependent kinase 8 in colon cancer. Am. J. Transl. Res. 2016, 8, 2088-2096. [PubMed]

302. Feng, C.; Zhang, L.; Sun, Y.; Li, X.; Zhan, L.; Lou, Y.; Wang, Y.; Liu, L.; Zhang, Y. GDPD5, a target of miR-195-5p, is associated with metastasis and chemoresistance in colorectal cancer. Biomed. Pharmacother. 2018, 101, 945-952. [CrossRef] [PubMed]

303. Qu, J.; Zhao, L.; Zhang, P.; Wang, J.; Xu, N.; Mi, W.; Jiang, X.; Zhang, C.; Qu, J. MicroRNA-195 chemosensitizes colon cancer cells to the chemotherapeutic drug doxorubicin by targeting the first binding site of BCL2L2 mRNA. J. Cell. Physiol. 2015, 230, 535-545. [CrossRef] [PubMed]

304. Zheng, L.; Chen, J.; Zhou, Z.; He, Z. miR-195 enhances the radiosensitivity of colorectal cancer cells by suppressing CARM1. Onco. Targets. Ther. 2017, 10, 1027-1038. [CrossRef] [PubMed]

305. Bai, J.; Xu, J.; Zhao, J.; Zhang, R. lncRNA SNHG1 cooperated with miR-497/miR-195-5p to modify epithelial-mesenchymal transition underlying colorectal cancer exacerbation. J. Cell. Physiol. 2020, 235, 1453-1468. [CrossRef] [PubMed]

306. Li, S.; Lv, C.; Li, J.; Xie, T.; Liu, X.; Zheng, Z.; Qin, Z.; Hui, X.; Yu, Y. LncRNA LINC00473 promoted colorectal cancer cell proliferation and invasion by targeting miR-195 expression. Am. J. Transl. Res. 2021, 13, 6066-6075.

307. Gu, H.; Xu, Z.; Zhang, J.; Wei, Y.; Cheng, L.; Wang, J. circ_0038718 promotes colon cancer cell malignant progression via the miR-195-5p/Axin2 signaling axis and also effect Wnt/ $\beta$-catenin signal pathway. BMC Genom. 2021, 22, 1-17. [CrossRef]

308. Li, Y.; Zhu, Z.; Hou, X.; Sun, Y. LncRNA AFAP1-AS1 Promotes the Progression of Colorectal Cancer through miR-195-5p and WISP1. J. Oncol. 2021, 2021, 6242798. [CrossRef]

309. Ebert, M.S.; Neilson, J.R.; Sharp, P.A. MicroRNA sponges: Competitive inhibitors of small RNAs in mammalian cells. Nat. Methods 2007, 4, 721-726. [CrossRef]

310. Dey, N.; Das, F.; Ghosh-Choudhury, N.; Mandal, C.C.; Parekh, D.J.; Block, K.; Kasinath, B.S.; Abboud, H.E.; Choudhury, G.G microRNA-21 governs TORC1 activation in renal cancer cell proliferation and invasion. PLoS ONE 2012, 7, e37366. [CrossRef]

311. Liu, X.; Abraham, J.M.; Cheng, Y.; Wang, Z.; Wang, Z.; Zhang, G.; Ashktorab, H.; Smoot, D.T.; Cole, R.N.; Boronina, T.N.; et al Synthetic Circular RNA Functions as a miR-21 Sponge to Suppress Gastric Carcinoma Cell Proliferation. Mol. Ther. Nucleic Acids 2018, 13, 312-321. [CrossRef] [PubMed]

312. Monfared, H.; Jahangard, Y.; Nikkhah, M.; Mirnajafi-Zadeh, J.; Mowla, S.J. Potential therapeutic effects of exosomes packed with a miR-21-sponge construct in a rat model of glioblastoma. Front. Oncol. 2019, 9, 1-11. [CrossRef]

313. Wang, Z.; Ma, K.; Cheng, Y.; Abraham, J.M.; Liu, X.; Ke, X.; Wang, Z.; Meltzer, S.J. Synthetic circular multi-miR sponge simultaneously inhibits miR-21 and miR-93 in esophageal carcinoma. Lab. Investig. 2019, 99, 1442-1453. [CrossRef] [PubMed]

314. Zeng, K.; Chen, X.; Xu, M.; Liu, X.; Hu, X.; Xu, T.; Sun, H.; Pan, Y.; He, B.; Wang, S. CircHIPK3 promotes colorectal cancer growth and metastasis by sponging miR-7 article. Cell Death Dis. 2018, 9. [CrossRef] [PubMed]

315. Zhang, Z.; Fu, C.; Xu, Q.; Wei, X. Long non-coding RNA CASC7 inhibits the proliferation and migration of colon cancer cells via inhibiting microRNA-21. Biomed. Pharmacother. 2017, 95, 1644-1653. [CrossRef] [PubMed]

316. Yuan, Y.; Liu, W.; Zhang, Y.; Zhang, Y.; Sun, S. CircRNA circ_0026344 as a prognostic biomarker suppresses colorectal cancer progression via microRNA-21 and microRNA-31. Biochem. Biophys. Res. Commun. 2018, 503, 870-875. [CrossRef]

317. He, J.H.; Li, Y.G.; Han, Z.P.; Zhou, J.B.; Chen, W.M.; Lv, Y.B.; He, M.L.; Zuo, J.D.; Zheng, L. The CircRNA-ACAP2/Hsa-miR-21$5 \mathrm{p} /$ Tiam1 Regulatory Feedback Circuit Affects the Proliferation, Migration, and Invasion of Colon Cancer SW480 Cells. Cell. Physiol. Biochem. 2018, 49, 1539-1550. [CrossRef]

318. Jiang, Z.; Hou, Z.; Li, L.; Liu, W.; Yu, Z.; Chen, S. Exosomal circEPB41L2 serves as a sponge for miR-21-5p and miR-942-5p to suppress colorectal cancer progression by regulating the PTEN/AKT signalling pathway. Eur. J. Clin. Investig. 2021, 51, e13581. [CrossRef]

319. Huang, H.; Yang, X.; Chen, J.; Fu, J.; Chen, C.; Wen, J.; Mo, Q. IncRNA DGCR5 inhibits the proliferation of colorectal cancer cells by downregulating miR-21. Oncol. Lett. 2019, 18, 3331-3336. [CrossRef]

320. Li, G.; Wang, C.; Wang, Y.; Xu, B.; Zhang, W. LINC00312 represses proliferation and metastasis of colorectal cancer cells by regulation of miR-21. J. Cell. Mol. Med. 2018, 22, 5565-5572. [CrossRef] 
321. Cai, Y.; Li, Y.; Shi, C.; Zhang, Z.; Xu, J.; Sun, B. LncRNA OTUD6B-AS1 inhibits many cellular processes in colorectal cancer by sponging miR-21-5p and regulating PNRC2. Hum. Exp. Toxicol. 2021, 40, 1463-1473. [CrossRef] [PubMed]

322. Han, K.; Wang, F.W.; Cao, C.H.; Ling, H.; Chen, J.W.; Chen, R.X.; Feng, Z.H.; Luo, J.; Jin, X.H.; Duan, J.L.; et al. CircLONP2 enhances colorectal carcinoma invasion and metastasis through modulating the maturation and exosomal dissemination of microRNA-17. Mol. Cancer 2020, 19, 1-18. [CrossRef] [PubMed]

323. Wen, R.; Chen, C.; Zhong, X.; Hu, C. PAX6 upstream antisense RNA (PAUPAR) inhibits colorectal cancer progression through modulation of the microRNA (miR)-17-5p / zinc finger protein 750 (ZNF750) axis. Bioengineered 2021, 12, 3886-3899. [CrossRef] [PubMed]

324. Yin, S.L.; Xiao, F.; Liu, Y.F.; Chen, H.; Guo, G.C. Long non-coding RNA FENDRR restrains the aggressiveness of CRC via regulating miR-18a-5p/ING4 axis. J. Cell. Biochem. 2020, 121, 3973-3985. [CrossRef]

325. Horita, K.; Kurosaki, H.; Nakatake, M.; Ito, M.; Kono, H.; Nakamura, T. Long noncoding RNA UCA1 enhances sensitivity to oncolytic vaccinia virus by sponging miR-18a/miR-182 and modulating the Cdc42/filopodia axis in colorectal cancer. Biochem. Biophys. Res. Commun. 2019, 516, 831-838. [CrossRef]

326. Li, Y.; Lv, S.; Ning, H.; Li, K.; Zhou, X.; Xv, H.; Wen, H. Down-regulation of CASC2 contributes to cisplatin resistance in gastric cancer by sponging miR-19a. Biomed. Pharmacother. 2018, 108, 1775-1782. [CrossRef]

327. Shen, P.; Qu, L.; Wang, J.; Ding, Q.; Zhou, C.; Xie, R.; Wang, H.; Ji, G. LncRNA LINC00342 contributes to the growth and metastasis of colorectal cancer via targeting miR-19a-3p/NPEPL1 axis. Cancer Cell Int. 2021, 21, 1-11. [CrossRef]

328. Dai, W.; Zeng, W.; Lee, D. lncRNA MCM3AP-AS1 inhibits the progression of colorectal cancer via the miR-19a-3p/FOXF2 axis. J. Gene Med. 2021, 23, 1-13. [CrossRef]

329. Jiang, Z.; Li, L.; Hou, Z.; Liu, W.; Wang, H.; Zhou, T.; Li, Y.; Chen, S. LncRNA HAND2-AS1 inhibits 5-fluorouracil resistance by modulating miR-20a/PDCD4 axis in colorectal cancer. Cell. Signal. 2020, 66, 109483. [CrossRef]

330. Zhang, G.; Liu, Z.; Zhong, J.; Lin, L. Circ-ACAP2 facilitates the progression of colorectal cancer through mediating miR-1433p/FZD4 axis. Eur. J. Clin. Investig. 2021, 51, e13607. [CrossRef]

331. Huang, F.; Wen, C.; Zhuansun, Y.; Huang, L.; Chen, W.; Yang, X.; Liu, H. A novel long noncoding RNA OECC promotes colorectal cancer development and is negatively regulated by miR-143-3p. Biochem. Biophys. Res. Commun. 2018, 503, 2949-2955. [CrossRef] [PubMed]

332. Zhao, L.; Li, Y.; Song, A. Inhibition of lncRNA TMPO-AS1 suppresses proliferation, migration and invasion of colorectal cancer cells by targeting miR-143-3p. Mol. Med. Rep. 2020, 22, 3245-3254. [CrossRef] [PubMed]

333. Liu, A.; Liu, L. Long non-coding RNA ZEB2-AS1 promotes proliferation and inhibits apoptosis of colon cancer cells via miR143/bcl-2 axis. Am. J. Transl. Res. 2019, 11, 5240-5248. [PubMed]

334. Gao, R.; Fang, C.; Xu, J.; Tan, H.; Li, P.; Ma, L. LncRNA CACS15 contributes to oxaliplatin resistance in colorectal cancer by positively regulating ABCC1 through sponging miR-145. Arch. Biochem. Biophys. 2019, 663, 183-191. [CrossRef] [PubMed]

335. Chen, Z.L.; Li, X.N.; Ye, C.X.; Chen, H.Y.; Wang, Z.J. Elevated levels of circrunx1 in colorectal cancer promote cell growth and metastasis via MiR-145-5p/IGF1 signalling. Onco. Targets. Ther. 2020, 13, 4035-4048. [CrossRef] [PubMed]

336. Bahreini, F.; Saidijam, M.; Mousivand, Z.; Najafi, R.; Afshar, S. Assessment of lncRNA DANCR, miR-145-5p and NRAS axis as biomarkers for the diagnosis of colorectal cancer. Mol. Biol. Rep. 2021, 48, 3541-3547. [CrossRef] [PubMed]

337. Wei, F.; Wang, M.; Li, Z.; Wang, Y.; Zhou, Y. Long Non-coding RNA MIR570MG Causes Regorafenib Resistance in Colon Cancer by Repressing miR-145/SMAD3 Signaling. Front. Oncol. 2020, 10, 1-13. [CrossRef]

338. Wang, Z.; Su, M.; Xiang, B.; Zhao, K.; Qin, B. Circular RNA PVT1 promotes metastasis via miR-145 sponging in CRC. Biochem. Biophys. Res. Commun. 2019, 512, 716-722. [CrossRef]

339. Tian, T.; Qiu, R.; Qiu, X. SNHG1 promotes cell proliferation by acting as a sponge of miR- 145 in colorectal cancer. Oncotarget 2018, 9, 2128-2139. [CrossRef]

340. Wei, A.W.; Li, L.F. Long non-coding RNA SOX21-AS1 sponges miR-145 to promote the tumorigenesis of colorectal cancer by targeting MYO6. Biomed. Pharmacother. 2017, 96, 953-959. [CrossRef]

341. Wang, X.; Bai, X.; Yan, Z.; Guo, X.; Zhang, Y. The lncRNA TUG1 promotes cell growth and migration in colorectal cancer via the TUG1-miR-145-5p-TRPC6 pathway. Biochem. Cell Biol. 2021, 99, 249-260. [CrossRef] [PubMed]

342. Bao, Y.; Tang, J.; Qian, Y.; Sun, T.; Chen, H.; Chen, Z.; Sun, D.; Zhong, M.; Chen, H.; Hong, J.; et al. Long noncoding RNA BFAL1 mediates enterotoxigenic Bacteroides fragilis-related carcinogenesis in colorectal cancer via the RHEB/mTOR pathway. Cell Death Dis. 2019, 10, 1-14. [CrossRef] [PubMed]

343. Li, Y.; Lu, Y.; Chen, Y. Long non-coding RNA SNHG16 affects cell proliferation and predicts a poor prognosis in patients with colorectal cancer via sponging MIR-200a-3p. Biosci. Rep. 2019, 39, 1-10. [CrossRef] [PubMed]

344. Jiao, M.; Ning, S.; Chen, J.; Chen, L.; Jiao, M.; Cui, Z.; Guo, L.; Mu, W.; Yang, H. Long non-coding RNA ZEB1-AS1 predicts a poor prognosis and promotes cancer progression through the miR-200a/ZEB1 signaling pathway in intrahepatic cholangiocarcinoma. Int. J. Oncol. 2020, 56, 1455-1467. [CrossRef] [PubMed]

345. Chen, D.L.; Chen, L.Z.; Lu, Y.X.; Zhang, D.S.; Zeng, Z.L.; Pan, Z.Z.; Huang, P.; Wang, F.H.; Li, Y.H.; Ju, H.Q.; et al. Long noncoding rna xist expedites metastasis and modulates epithelial-mesenchymal transition in colorectal cancer. Cell Death Dis. 2017, 8, e3011. [CrossRef]

346. Gao, Z.; Zhou, H.; Wang, Y.; Chen, J.; Ou, Y. Regulatory effects of lncRNA ATB targeting miR-200c on proliferation and apoptosis of colorectal cancer cells. J. Cell. Biochem. 2020, 121, 332-343. [CrossRef] 
347. Liu, X.; Wang, C. Long non-coding RNA ATB is associated with metastases and promotes cell invasion in colorectal cancer via sponging miR-141-3p. Exp. Ther. Med. 2020, 20, 1. [CrossRef]

348. Ren, J.; Ding, L.; Zhang, D.; Shi, G.; Xu, Q.; Shen, S.; Wang, Y.; Wang, T.; Hou, Y. Carcinoma-associated fibroblasts promote the stemness and chemoresistance of colorectal cancer by transferring exosomal lncRNA H19. Theranostics 2018, 8, 3932-3948. [CrossRef]

349. Sun, Z.; Shao, B.; Liu, Z.; Dang, Q.; Guo, Y.; Chen, C.; Guo, Y.; Chen, Z.; Liu, J.; Hu, S.; et al. LINC01296/miR-141-3p/ZEB1-ZEB2 axis promotes tumor metastasis via enhancing epithelial-mesenchymal transition process. J. Cancer 2021, 12, 2723-2734. [CrossRef]

350. Wang, H.; Li, H.; Zhang, L.; Yang, D. Overexpression of MEG3 sensitizes colorectal cancer cells to oxaliplatin through regulation of miR-141/PDCD4 axis. Biomed. Pharmacother. 2018, 106, 1607-1615. [CrossRef]

351. Deng, Z.; Li, X.; Wang, H.; Geng, Y.; Cai, Y.; Tang, Y.; Wang, Y.; Yu, X.; Li, L.; Li, R. Dysregulation of CircRNA_0001946 Contributes to the Proliferation and Metastasis of Colorectal Cancer Cells by Targeting MicroRNA-135a-5p. Front. Genet. 2020, 11, 1-12. [CrossRef] [PubMed]

352. Wu, Q.; Shi, M.; Meng, W.; Wang, Y.; Hui, P.; Ma, J. Long noncoding RNA FOXD3-AS1 promotes colon adenocarcinoma progression and functions as a competing endogenous RNA to regulate SIRT1 by sponging miR-135a-5p. J. Cell. Physiol. 2019, 234, 21889-21902. [CrossRef]

353. Zhou, D.; He, S.; Zhang, D.; Lv, Z.; Yu, J.; Li, Q.; Li, M.; Guo, W.; Qi, F. LINC00857 promotes colorectal cancer progression by sponging miR-150-5p and upregulating HMGB3 (high mobility group box 3) expression. Bioengineered 2021, 12, 12107-12122 [CrossRef] [PubMed]

354. Wang, X.; Jiang, G.; Ren, W.; Wang, B.; Yang, C.; Li, M. LncRNA NEAT1 regulates 5-fu sensitivity, apoptosis and invasion in colorectal cancer through the MiR-150-5p/CPSF4 axis. Onco. Targets. Ther. 2020, 13, 6373-6383. [CrossRef] [PubMed]

355. Shoshan, E.; Mobley, A.K.; Braeuer, R.R.; Kamiya, T.; Huang, L.; Vasquez, M.E.; Salameh, A.; Lee, H.J.; Kim, S.J.; Ivan, C.; et al. Hypo adenosine-to-inosine miR-455-5p editing promotes melanoma growth and metastasis. Nat. Cell Biol. 2015, 17, 311-321. [CrossRef]

356. Yang, X.; Zhang, S.; He, C.; Xue, P.; Zhang, L.; He, Z.; Zang, L.; Feng, B.; Sun, J.; Zheng, M. METTL14 suppresses proliferation and metastasis of colorectal cancer by down-regulating oncogenic long non-coding RNA XIST. Mol. Cancer 2020, 19, 1-16. [CrossRef]

357. Huang, Q.R.; Pan, X. Bin Prognostic lncRNAs, miRNAs, and mRNAs Form a Competing Endogenous RNA Network in Colon Cancer. Front. Oncol. 2019, 9, 712. [CrossRef]

358. Shuwen, H.; Qing, Z.; Yan, Z.; Xi, Y. Competitive endogenous RNA in colorectal cancer: A systematic review. Gene 2018, 645, 157-162. [CrossRef]

359. Wang, L.; Cho, K.B.; Li, Y.; Tao, G.; Xie, Z.; Guo, B. Long noncoding RNA (LncRNA)-mediated competing endogenous RNA networks provide novel potential biomarkers and therapeutic targets for colorectal cancer. Int. J. Mol. Sci. 2019, $20,5758$. [CrossRef]

360. Jung, G.; Hernández-Illán, E.; Moreira, L.; Balaguer, F.; Goel, A. Epigenetics of colorectal cancer: Biomarker and therapeutic potential. Nat. Rev. Gastroenterol. Hepatol. 2020, 17, 111-130. [CrossRef]

361. Qi, X.; Lin, Y.; Liu, X.; Chen, J.; Shen, B. Biomarker Discovery for the Carcinogenic Heterogeneity Between Colon and Rectal Cancers Based on lncRNA-Associated ceRNA Network Analysis. Front. Oncol. 2020, 10, 1-15. [CrossRef] [PubMed]

362. Liu, J.; Li, H.; Zheng, B.; Sun, L.; Yuan, Y.; Xing, C. Competitive Endogenous RNA (ceRNA) Regulation Network of lncRNAmiRNA-mRNA in Colorectal Carcinogenesis. Dig. Dis. Sci. 2019, 64, 1868-1877. [CrossRef] [PubMed]

363. Yuan, W.; Li, X.; Liu, L.; Wei, C.; Sun, D.; Peng, S.; Jiang, L. Comprehensive analysis of lncRNA-associated ceRNA network in colorectal cancer. Biochem. Biophys. Res. Commun. 2019, 508, 374-379. [CrossRef] [PubMed] 